\title{
Data report: permeability of mud(stone) samples from Site C0001, IODP Expedition 315, Nankai Trough: NanTroSEIZE Stage 1'
}

\author{
Lei Yue, ${ }^{2}$ William J. Likos, ${ }^{2,3}$ Junhua Guo, ${ }^{4}$ and Michael B. Underwood ${ }^{4}$
}

\section{Chapter contents}

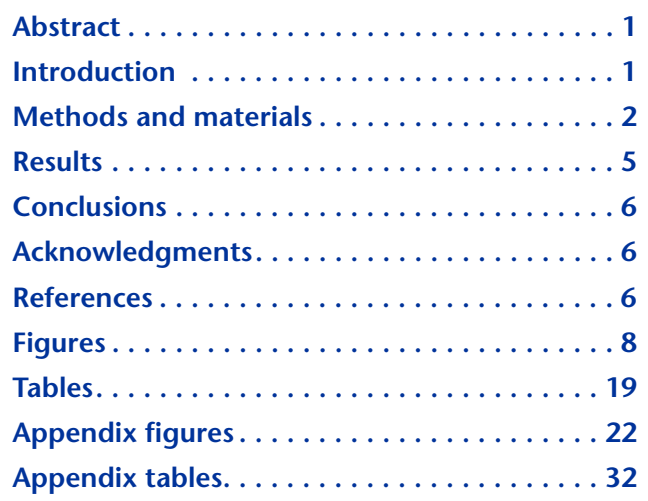

YYue, L., Likos, W.J., Guo, J., and Underwood, M.B., 2012. Data report: permeability of mud(stone) samples from Site C0001, IODP Expedition 315, Nankai Trough: NanTroSEIZE Stage 1. In Kinoshita, M., Tobin, H., Ashi, J., Kimura, G., Lallemant, S., Screaton, E.J., Curewitz, D., Masago, H., Moe, K.T., and the Expedition 314/315/316 Scientists, Proc. IODP, 314/315/316: Washington, DC (Integrated Ocean Drilling Program Management International, Inc.). doi:10.2204/iodp.proc.314315316.204.2012 2Department of Civil and Environmental Engineering, University of Missouri, Columbia MO, USA.

${ }^{3}$ Correspondence author: likosw@missouri.edu ${ }^{4}$ Department of Geological Sciences, University of Missouri, Columbia MO, USA.

\section{Abstract}

In this study, we conducted constant-flow permeability tests in the horizontal (cross-core) and vertical (along-core) directions using five whole-round core specimens of mud(stone) from Integrated Ocean Drilling Program (IODP) Site C0001. The site is located above the accretionary prism of the Nankai Trough offshore of the Kii Peninsula, Japan. The samples came from depths of approximately 25 to $290 \mathrm{~m}$ below seafloor and include lithologic Units I (slope apron facies) and II (upper accretionary prism). Effective isotropic confining stress during the tests was set at five increments ranging from $0.034 \mathrm{MPa}(5 \mathrm{psi})$ to $0.551 \mathrm{MPa}(80 \mathrm{psi})$. Average values of hydraulic conductivity range from $1.06 \times 10^{-8}$ to $7.30 \times 10^{-7} \mathrm{~cm} / \mathrm{s}$. Corresponding values of intrinsic permeability range from $\sim 10^{-17}$ to $10^{-16} \mathrm{~m}^{2}$. The ratio of horizontal to vertical permeability $\left(k_{\mathrm{h}} / k_{\mathrm{v}}\right)$ averages 1.15 . Environmental scanning electron microscopy was used to assess the relation between the sediment's microstructure and the anisotropy of permeability. Indicators of anisotropy generally show modestly better alignment of grains in the horizontal direction.

\section{Introduction}

Earthquakes and tsunamis are among the most unpredictable and destructive natural disasters, sometimes destroying life as well as buildings on a massive scale. Particularly destructive are those earthquakes occurring in subduction zones. Recent examples include the Sumatra earthquake and tsunami in 2004 and the earthquake and tsunami off the coast of Sendai (Tohoku) Japan in 2011.

To better understand how and why earthquakes and tsunamis occur in subduction zones, it is useful to measure the mechanical and hydrological properties of sediments and sedimentary rocks retrieved by scientific ocean drilling. Among those many properties, permeability has an important influence on sediment consolidation and strength through its affect on pore fluid pressure (Moore and Vrolijk, 1992; Saffer and Bekins, 2006). By characterizing hydrological properties both within and adjacent to fault zones at various depths, we can examine how geologic structures and permeability might influence one another over a range of effective stress values, thereby improving the understanding of fault dynamics. 
In this report, we present the results of constant-flow permeability tests that were completed at the University of Missouri on whole-round core specimens retrieved from the Nankai Trough accretionary prism offshore Japan (Fig. F1). Three holes were cored at Integrated Ocean Drilling Program (IODP) Site C0001 during Expedition 315 ("Expedition 315 Site C0001" chapter [Expedition 315 Scientists, 2009]). All of the sampling at Site C0001 was limited to the hanging wall of a megasplay fault (see Moore et al., 2009). Six whole-round samples were collected for this study, with subbottom depths ranging from 25.21 to $400.33 \mathrm{~m}$ core depth below seafloor (CSF) (Fig. F1). The upper three samples come from lithologic Unit I (slope apron facies), whereas the lower three are from Unit II (upper accretionary prism). Bedding dips at the sampling depths are also shown on Figure F1. Unfortunately, the deepest sample could not be tested successfully because of severe fracturing.

Previous laboratory tests of natural clay-rich sediment and shale tend to show large ranges in permeability values because of differences in the material's mineral composition and texture (Bennett et al., 1989; Neuzil, 1994; Dewhurst et al., 1999; Yang and Aplin, 2007; Gamage et al., 2011). Of particular interest to our study is the anisotropy of permeability (e.g., Clennell et al., 1999, Bolton et al., 2000) because that property is likely to change in response to tectonic loading and fault-related deformation. Typically, comparisons are made between horizontal (cross-core) permeability $\left(k_{\mathrm{h}}\right)$ and vertical (alongcore) permeability $\left(k_{\mathrm{v}}\right)$ at the same sampling depth. A sediment or sedimentary rock is considered isotropic if the hydraulic conductivity (or intrinsic permeability) is the same in every direction $\left(k_{\mathrm{h}}=k_{\mathrm{v}}\right)$ and anisotropic if hydraulic conductivity or permeability is unequal in different directions. In most cases, preferred alignment of platy mineral grains results in $k_{\mathrm{h}}$ $>k_{\mathrm{v}}$ with the $k_{\mathrm{h}} / k_{\mathrm{v}}$ ratio for soils ranging from $<1$ to $>10$ (Mitchell, 1993).

Permeability anisotropy usually varies with the thickness of sedimentary layering (varves, laminae, etc.), depth of burial, and magnitude of applied effective stress. In most sedimentary basins, long-term burial loading and chemical diagenesis impart changes in the volume and orientation of platy clay minerals. The alignment of grains becomes almost perpendicular to the maximum principal effective stress (Sintubin, 1994; Anandarajah and Kuganenthira, 1995; Kim et al., 1999; Aplin et al., 2006), and fluids physically seek the more conductive flow path along rather than across their direction of alignment (Golin et al., 1992). In subduction systems, the orientation of maximum principal effective stress and grain fabric may change because of tectonic loading and/or shearing. The hydrological properties of sediment, moreover, depend on many inherited factors, including grain size and shape, sorting, the type of geometric arrangement, and the magnitude of the interparticle forces (Moon and Hurst, 1984; Bennett et al., 1989, 1991). Different scales of fabric also need to be taken into account (Mitchell, 1993). Microfabric refers to the aggregation of particles and very small pores, whereas minifabric contains larger pores, cracks, fissures, or laminations between aggregate assemblages, which can measure up to several tens of micrometers. Fluid flow tends to be enhanced through the larger interaggregate pores as opposed to the tiny intra-aggregate pores (Olsen, 1960; Delage and Lefebvre, 1984). When sediments are compressed at increasing effective stress levels, the collapse of structure is progressive. In general, the largest interaggregate pores are affected first, and as consolidation proceeds, smaller pores are affected. A structural anisotropy therefore develops with increasing compression and lithification (Delage and Lefebvre, 1984; Moon and Hurst, 1984).

With these complications in mind, the primary purpose of our study is to quantify the degree of permeability anisotropy at shallow levels of the Nankai Trough subduction system. A second objective is to relate depth-dependent changes, if any, to variations in the development of grain fabric within the two lithologic units (slope apron and upper accretionary prism).

\section{Methods and materials}

\section{Specimen preparation}

Soon after recovery of a given core aboard the $\mathrm{D} / \mathrm{V}$ Chikyu, the whole-round samples were cut, capped and taped in their plastic core liners, and sealed in aluminum vacuum bags with moist sponges to prevent moisture loss. The samples were stored at $4^{\circ} \mathrm{C}$ until immediately prior to trimming. To extract each specimen, the plastic core liner was cut lengthwise along two lines $180^{\circ}$ apart using a hacksaw and then removed. Cylindrical specimens for permeability tests in the vertical core direction were trimmed using a wire saw and soil lathe from the top $7 \mathrm{~cm}$ of each whole-round sample. Sample dimensions were measured at several points using a caliper to a resolution of $\pm 0.03 \mathrm{~cm}$ and averaged to obtain values used for subsequent calculations. Specimen length after trimming ranged from 4.4 to $5.9 \mathrm{~cm}$ and averaged $5.3 \mathrm{~cm}$ (Table T1). Specimen diameter ranged from 3.4 to $4.1 \mathrm{~cm}$ and averaged $3.8 \mathrm{~cm}$. Separate specimens for permeability tests in the horizontal direction were trimmed from the remaining material lo- 
cated immediately below the top $7 \mathrm{~cm}$ taken for vertical permeability testing. These specimens were trimmed perpendicular to the core axis. Bedding orientation (dip angle) with respect to the core axis (Fig. F1) was not taken into account during trimming, but that factor could exert some influence on the apparent magnitude of permeability anisotropy.

Specimen trimmings were retained and used for measurements of liquid limit (LL), plastic limit (PL), and corresponding plasticity index (PI) following procedures outlined in ASTM Standard D4318-05 (ASTM International, 2005) (Table T1). Initial specimen porosity $\left(n_{\mathrm{i}}\right)$ was estimated from gravimetric water content $\left(w_{\mathrm{i}}\right)$ of the specimen trimmings by assuming $100 \%$ pore water saturation and a specific gravity of the mineral solids of 2.70 . Gravimetric water content of the specimen trimmings was determined by oven-drying at $105^{\circ} \mathrm{C}$. Additional information reported on Table T1 includes Skempton's Bvalue determined to assess specimen saturation (see subsequent discussion) and final water content and porosity $\left(w_{\mathrm{f}}\right.$ and $n_{\mathrm{f}}$ ) measured from oven drying portions of the specimens after permeability testing. Values reported on Table T1 are those taken after isotropically consolidating the specimens to $\sim 0.55 \mathrm{MPa}$ effective stress. Computed porosities were not corrected to account for the presence of tightly adsorbed water associated with smectite content (e.g., Brown et al., 2001; Gamage et al., 2011), nor was porosity corrected for the presence of salt in the pore water.

\section{Constant-flow apparatus}

Constant-flow, flow-through permeability tests were used to determine hydraulic conductivity in the vertical and horizontal core directions. The constantflow method employs an infuse/withdrawal syringe pump to simultaneously inject and extract pore fluid from the top and bottom of the specimen. The closed system in use at the University of Missouri consists of an acrylic confining cell to contain the specimen and provide isotropic effective stress, a constant-flow infuse/withdrawal syringe pump, one differential pressure transducer to measure hydraulic head loss between the specimen top cap and bottom cap, and an air/water interface panel for regulating the confining fluid pressure and pore fluid backpressure (Fig. F2). A digital interface displays and records effective stress $\left(\sigma^{\prime}\right)$, change of hydraulic head $(\Delta h)$, and time duration measurements made during each test run. Signals from the pressure transducer were acquired to obtain head loss at a precision of $\pm 1 \mathrm{~cm}$ $\mathrm{H}_{2} \mathrm{O}$ over a range spanning $\pm 1000 \mathrm{~cm} \mathrm{H}_{2} \mathrm{O}$. The flow pump (KDS Scientific, Model 260) holds two syringes (Hamilton GasTight Series 1000) and has the capabil- ity to cycle continuously back and forth in a pushpull action. As one syringe infuses pore fluid into the specimen, the other withdraws an equal volume of fluid from the other end of the specimen at the same rate. At the end of the set volume, the direction is automatically reversed and the next cycle begins. With the use of three-way valves, the pump can empty and refill syringes for a continuous dispense. Volumetric flow rate $(Q)$ for the series of tests described here ranged from a minimum of 0.00025 $\mathrm{cm}^{3} / \mathrm{min}$ to a maximum of $0.010 \mathrm{~cm}^{3} / \mathrm{min}$, resulting in a corresponding discharge (Darcy) velocity $(v)$ that ranged from approximately $3.50 \times 10^{-7}$ to $1.37 \times 10^{-5}$ $\mathrm{cm} / \mathrm{s}$.

\section{Backpressure saturation}

Prior to testing, all permeant lines and porous stones were saturated with simulated seawater $(25 \mathrm{~g} \mathrm{NaCl}$ to $1 \mathrm{~L}$ tap water). A specimen was placed on the pedestal, the top cap applied, and a latex membrane placed on the specimen using a vacuum membrane expander. The confining chamber was then sealed and the cell was filled with tap water. Saturation of the specimen was achieved by ramping pore fluid backpressure to $70 \mathrm{psi}(0.48 \mathrm{MPa})$ while also ramping the confining pressure to maintain an effective isotropic confining stress of 5 psi $(0.034 \mathrm{MPa})$. Elevated backpressure was maintained for at least $24 \mathrm{~h}$. Saturation of the specimen was checked by increasing the confining pressure $(\sigma)$ to 80 psi $(0.55 \mathrm{MPa})$ and measuring the corresponding pore pressure $(u)$ response and calculating Skempton's $B$-value $(B=\Delta u / \Delta \sigma)$. Specimens were considered saturated if $B \geq 0.95$ (Table T1). Once saturation was achieved, the cell confining pressure was increased to consolidate the specimen at a desired effective stress. Pore water was allowed to drain during consolidation from both the top and bottom of the specimen.

\section{Constant-flow permeation}

Constant-flow tests were performed for each of the 10 specimens ( 5 trimmed vertically and 5 trimmed horizontally) at five increasing levels of effective stress: 5 psi $(0.034 \mathrm{MPa}), 20$ psi $(0.138 \mathrm{MPa}), 40 \mathrm{psi}$ $(0.276 \mathrm{MPa}), 60 \mathrm{psi}(0.414 \mathrm{MPa})$, and 80 psi $(0.551$ $\mathrm{MPa})$. Tests at each level of effective stress were conducted using four flow rates to obtain replicate permeability values, including two tests conducted with a top-to-bottom flow direction (denoted subsequently as a negative flow value) and two tests conducted with a bottom-to-top flow direction (denoted as a positive flow value) to obtain replicate permeability values. Transient response from the differential pressure transducer was monitored for steady-state head difference $\left(\Delta h_{s}\right)$, typically requiring $75-100 \mathrm{~min}$ 
per test run (e.g., Fig. F3). Values of applied discharge velocity $(v)$ and steady-state hydraulic gradient $\left(i_{s}\right)$ were plotted to assess consistency among the four test runs and linearity in the relationship (Figs. AF1, AF2, AF3, AF4, AF5, AF6, AF7, AF8, AF9, AF10). Coefficient of determination values $\left(R^{2}\right)$ by leastsquared linear regression of these $v$ and $i_{\mathrm{s}}$ values were $\geq 0.9835$, indicating good repeatability among the four flow tests conducted at each level of confining stress and the validity of Darcy's Law (Equation 1) for calculating hydraulic conductivity.

\section{Data analysis}

Hydraulic conductivity $(K)$ was calculated for each specimen using Darcy's law:

$$
Q=K i_{\mathrm{s}} A=K\left[\Delta h_{\mathrm{s}} / \Delta L\right] A,
$$

where

$Q=$ applied volumetric flow rate $\left(\mathrm{cm}^{3} / \mathrm{s}\right)$,

$i_{\mathrm{S}}=$ steady-state hydraulic gradient equal to the ratio of the steady-state head loss $\left(\Delta h_{\mathrm{s}}\right)$ to the length over which that head loss occurs $(\Delta L)$ (taken as the initial height of the specimen), and

$A=$ cross-sectional flow area $\left(\mathrm{cm}^{2}\right)$ (taken as the initial specimen area).

The corresponding discharge velocity is $v=Q / A$. Hydraulic conductivity values under laboratory test conditions (units for $K=\mathrm{cm} / \mathrm{s}$ ) were converted to intrinsic permeability $(k)\left(\mathrm{m}^{2}\right)$ values using

$$
k=(K \mu) / \rho g,
$$

where

$$
\begin{aligned}
\mu= & \text { viscosity of permeant }(0.001 \mathrm{~Pa} \cdot \mathrm{s} \text { at room tem- } \\
& \text { perature conditions }) \\
\rho= & \text { density of permeant }\left(1027 \mathrm{~kg} / \mathrm{m}^{3}\right), \text { and } \\
\mathrm{g}= & \text { gravitational acceleration }\left(9.81 \mathrm{~m} / \mathrm{s}^{2}\right) .
\end{aligned}
$$

\section{Imaging of grain fabric}

Specimens for imaging of grain fabric were cut from the whole-round samples with a razor blade at vertical orientation and horizontal orientation relative to the axis of the cylindrical samples (Fig. F4). Grain fabrics of wet, uncoated, and unfixed specimens were imaged using an FEI Quanta 600 FEG scanning electron microscope (SEM). The instrument operates in environmental mode (ESEM) at $30 \mathrm{kV}$, with the specimen chamber pressure set at $700 \mathrm{~Pa}$. Water vapor ( $\sim 98 \%$ humidity) from a built-in reservoir keeps the specimen from losing moisture. The temperature of the cooling stage was set to $2^{\circ} \mathrm{C}$. The specimens were imaged with a gaseous backscatter electron de- tector, spot $=3.0$ at a working distance of $\sim 10 \mathrm{~mm}$. This combination generates an imaging resolution of $\sim 4 \mathrm{~nm}$, and the dimensions of the field of view are about $145 \mu \mathrm{m} \times 130 \mu \mathrm{m}$ at $2000 \times$ magnification. Specimens were placed in the holder on the stage with the imaged surface facing upward. "Center stage" and "Tilt" commands of the ESEM controlling software were used to manually adjust the imaging face to an orientation as close to perpendicular as possible to the imaging beam. All the image files were saved with color gray mode in tiff format.

Digital images were processed using Image software (available at rsbweb.nih.gov/ij/index.html). Our processing steps adhere to the following:

1. Contrast enhancement: linear stretching of the gray-level histogram in order to use 256 graylevel values.

2. Median filter: moving each pixel value to the median values of 9 closest pixels (to reduce noise).

3. Mean filter: moving each pixel value to the mean values of 9 closest pixels weighted by its coefficient (to preserve subtle details).

4. Median hybrid filter: moving each pixel to the median values of middle horizontal 3 pixels, center vertical 3 pixels, and center pixel of those 9 closest pixels (to reduce noise while preserving linear features).

5. Threshold: adjusting and picking up one point of gray-level histogram (to select objects).

6. Make binary, to transform the gray image to white and black image (e.g., Fig. F5A).

7. Overlap the image onto the original image and set its alpha value (transparency) to 60\% in Photoshop software, then separate objects that touch, by manual adjustment with eraser tool (Fig. F5B, F5C).

8. Median filter with ImageJ, to remove objects $<8$ pixels in size (because measurements on small objects are mostly biased).

9. Fill the holes on the objects (Fig. F5D).

10. Measure automatically, to obtain the long-axis and short-axis dimensions and long-axis orientation of an object.

The software can automatically determine the long or short axis (apparent dimensions) of the objects in the 2-D image. Results are saved in a text file automatically after measurement.

Orientation of grain fabric was quantitatively characterized in the form of rose diagrams depicting orientations of the apparent long particle axes. In petrography, SEM, and transmission electron microscopy studies, most investigators measure between 100 and 500 grains per thin or ultrathin section (Krumbein, 1935; Friedman, 1958; van der Plas, 1962; Griffiths, 
1967; Chiou et al., 1991). The orientation of each particle (apparent long axis) was assigned to an angle between $0^{\circ}$ and $180^{\circ}$. For the vertical section, the core axis is oriented at $90^{\circ}$. We depict all the measured orientations as rose diagrams using Rozeta software (available at www.softpedia.com/get/ScienceCAD/Rozeta.shtml). This software automatically counts the number of particles according to their orientation and combines data into bins of $10^{\circ}$. In addition to the rose diagram, the number of values in each bin was summed and normalized to a total of $100 \%$. Cumulative frequency curves were constructed to show the distribution of grain orientations (Chiou et al., 1991).

Various statistical methods can be used to characterize the degree of orientation, such as the formulas of Folk and Ward (1957), Martínez-Nistal et al. (1999), and Zaniewski and Van Der Meer (2005). The Folk and Ward (1957) formula was proposed originally to graphically compute values of sorting (standard deviation) for grain size data. The equivalent equation for standard deviation of grain of orientation $(d)$ equals

$$
d=\left[\left(\phi_{84}-\phi_{16}\right) / 4\right]+\left[\left(\phi_{95}-\phi_{5}\right) / 6.6\right],
$$

where $\phi_{84}, \phi_{16}, \phi_{95}$, and $\phi_{5}$ represent the angle of orientation at the 84th, 16th, 95th, and 5th percentiles, respectively, on the cumulative frequency curve. This graphical technique avoids the laborious calculations required by moment statistics (Chiou et al., 1991). If the fabric of sediment shows strong preferred orientation, then the sorting of orientation angles will be better and the slope of cumulative frequency curve will be steeper near the median (50th percentile). In theory, the maximum value of $d$ is $72.3^{\circ}$ (e.g., a case in which $\phi_{16}$ and $\phi_{5}=0^{\circ}$ and $\phi_{84}$ and $\left.\phi_{95}=180^{\circ}\right)$. We normalized each standard deviation to this maximum value by calculating the "index of microfabric orientation" (i) as shown the following formula:

$$
i=1-(d / 72.3) \text {. }
$$

The closer $i$ is to 1 , the more particles are aligned in a preferred direction. For a highly random arrangement of particles, the cumulative curve generally has a slope of $<0.75$ near the median, the standard deviation of orientation is $>35^{\circ}$, and the index of microfabric orientation is $<0.51$. For well-oriented clay particles, the slope of the cumulative curve is generally $>1.00$ near the median, the standard deviation of ori- entation is $<25^{\circ}$, and the index of microfabric orientation is $>0.65$.

\section{Results}

We present a series of tables in the Appendix (Tables AT1, AT2, AT3, AT4, AT5, AT6, AT7, AT8, AT9, AT10) to summarize volumetric flow rate $(Q)$, discharge velocity $(v)$, steady-state head loss $\left(\Delta h_{\mathrm{s}}\right)$, steady-state hydraulic gradient $\left(i_{s}\right)$, hydraulic conductivity $(K)$, and intrinsic permeability $(k)$ from four test runs conducted for each specimen at five levels of effective stress $\left(\sigma^{\prime}\right)$. Table T2 summarizes the average values of vertical $\left(k_{\mathrm{v}}\right)$ and horizontal $\left(k_{\mathrm{h}}\right)$ permeability and the corresponding $k_{\mathrm{h}} / k_{\mathrm{v}}$ ratio for each specimen.

Figure F6A and F6B shows vertical and horizontal permeability as a function of increasing effective isotropic confining stress. Permeability in each direction shows a generally decreasing trend with effective stress. The most significant reductions in vertical permeability with stress occur for the two relatively shallow samples (25.21 and $129.22 \mathrm{~m} \mathrm{CSF}$ ), as well as for the deeper sample at $214.83 \mathrm{~m}$ CSF. The most significant reductions in horizontal permeability occur for the two shallowest samples. In each case, permeability appears to trend toward an asymptote as the highest level of effective stress is approached.

Figure F7 shows the distribution of vertical and horizontal permeability and the corresponding $k_{\mathrm{h}} / k_{\mathrm{v}}$ ratio with sampling depth. The general trend is for $k$ values to decrease with depth, and the $k_{\mathrm{h}} / k_{\mathrm{v}}$ ratio is consistently $\geq 1$. Figure F8 shows the $k_{\mathrm{h}} / k_{\mathrm{v}}$ ratio for all five samples as a function of effective stress. With the exception of samples from 129.22 and $214.83 \mathrm{~m} \mathrm{CSF}$ at effective stress $<0.3 \mathrm{MPa}$, the $k_{\mathrm{h}} / k_{\mathrm{v}}$ ratio is near or $>1$. Consolidation of these two samples tends to increase the anisotropy ratio, whereas consolidation of samples with higher initial anisotropy ratios tends to decrease, or have little effect on, the ratio.

Figure F9 shows how permeability changes with porosity for tests conducted at the highest magnitude of effective confining stress $(0.55 \mathrm{MPa})$. Porosity values are calculated from the posttest measurements of water content (Table T1). The general trend shows that permeability decreases as porosity decreases.

Figure F10 shows rose diagrams with corresponding values for the standard deviation of grain and the index of microfabric orientation calculated using Equations 3 and 4, respectively. These statistics are sum- 
marized on Table T3. Figure F11 shows cumulative frequency curves for the grain orientations. These statistics are consistent with random grain orientations. There is no uniform relation between preferred grain alignment and the orientation of imaging surfaces (relative to the core axis) or to the orientation of bedding planes.

\section{Conclusions}

The highest value of vertical hydraulic conductivity calculated for these samples is $7.30 \times 10^{-7} \mathrm{~cm} / \mathrm{s}$ with corresponding intrinsic permeability of $7.25 \times 10^{-16}$ $\mathrm{m}^{2}$. The lowest value of vertical hydraulic conductivity is $1.06 \times 10^{-8} \mathrm{~cm} / \mathrm{s}\left(1.05 \times 10^{-17} \mathrm{~m}^{2}\right)$. The highest value of horizontal hydraulic conductivity is $5.01 \times$ $10^{-7} \mathrm{~cm} / \mathrm{s}\left(4.97 \times 10^{-16} \mathrm{~m}^{2}\right)$, and the lowest value of horizontal hydraulic conductivity is $1.35 \times 10^{-8} \mathrm{~cm} / \mathrm{s}$ $\left(1.34 \times 10^{-17} \mathrm{~m}^{2}\right)$. The mean anisotropy ratio for permeability is 1.15 , and the range for anisotropy ratio is $0.44-1.56$. Imaging of the microfabric shows that arrangements of particles are mostly random. A majority of values for the standard deviation of grain orientation from vertical sections are greater than those from horizontal sections. The indexes of microfabric orientation do not show a systematic trend with increasing burial depth.

\section{Acknowledgments}

Samples were provided by the Integrated Ocean Drilling Program (IODP). We thank the crew, technicians, and shipboard scientists aboard the D/V Chikyu for their assistance in acquisition of the samples during Expedition 315. This study was supported by Grants T315A58 and T315B58 from the U.S. Scientific Support Program (Consortium for Ocean Leadership) and the National Science Foundation (Grant OCE-0751819). Louis Ross provided expert guidance with ESEM imaging, and K. Gamage provided a useful review of the manuscript.

\section{References}

Anandarajah, A., and Kuganenthira, N., 1995. Some aspects of fabric anisotropy of soil. Géotechnique, 45(1):69-81. doi:10.1680/geot.1995.45.1.69

Aplin, A.C., Matenaar, I.F., McCarty, D.K., and van der Pluijm, B.A., 2006. Influence of mechanical compaction and clay mineral diagenesis on the microfabric and pore-scale properties of deep-water Gulf of Mexico mudstones. Clays Clay Miner., 54(4):500-514. doi:10.1346/ CCMN.2006.0540411

ASTM International, 2005. Standard test methods for liquid limit, plastic limit, and plasticity index of soils
(Standard D4318-05). In Annual Book of ASTM Standards (Vol. 04.08): West Conshohocken, PA. (Am. Soc. Testing Mater.). doi:10.1520/D4318-05

Bennett, R.H., Fischer, K.M., Lavoie, D.L., Bryant, W.R., and Rezak, R., 1989. Porometry and fabric of marine clay and carbonate sediments: determinants of permeability. Mar. Geol., 89(1-2):127-152. doi:10.1016/00253227(89)90030-3

Bennett, R.H., O’Brien, N.R., and Hulbert, M.H., 1991. Determinants of clay and shale microfabric signatures: processes and mechanisms. In Bennett, R.H., Bryant, W.R., and Hulbert, M.H. (Eds.), Microstructure of FineGrained Sediments: From Mud to Shale: New York (Springer-Verlag), 5-32.

Bolton, A.J., Maltman, A.J., and Fisher, Q., 2000. Anisotropic permeability and bimodal pore-size distributions of fine-grained marine sediments. Mar. Pet. Geol., 17(6):657-672. doi:10.1016/S0264-8172(00)00019-2

Brown, K.M., Saffer, D.M., and Bekins, B.A., 2001. Smectite diagenesis, pore-water freshening, and fluid flow at the toe of the Nankai wedge. Earth Planet. Sci. Lett., 194(12):97-109. doi:10.1016/S0012-821X(01)00546-5

Chiou, W.-A., Bennett, R.H., and Bryant, W.R., 1991. Quantification of clay fabric: a simple technique. In Bennett, R.H., Bryant, W.R., and Hulbert, M.H. (Eds.), Microstructure of Fine-Grained Sediments: From Mud to Shale: New York (Springer-Verlag), 379-387.

Clennell, M.B., Dewhurst, D.N., Brown, K.M., and Westbrook, G.K., 1999. Permeability anisotropy of consolidated clays. In Aplin, A.C., Fleet, A.J., and MacQuaker, J.H.S. (Eds.), Muds and Mudstones: Physical and Fluid-Flow Properties. Geol. Soc. Spec. Publ., 158(1):79-96. doi:10.1144/GSL.SP.1999.158.01.07

Delage, P., and Lefebvre, G., 1984. Study of the structure of a sensitive Champlain clay and its evolution during consolidation. Can. Geotech. J., 21(1):21-35. doi:10.1139/t84-003

Dewhurst, D.N., Yang, Y., and Aplin, A.C., 1999. Permeability and fluid flow in natural mudstones. In Aplin, A.C., Fleet, A.J., and MacQuaker, J.H.S. (Eds.), Muds and Mudstones: Physical and Fluid-Flow Properties. Geol. Soc. Spec. Publ., 158(1):23-43. doi:10.1144/ GSL.SP.1999.158.01.03

Expedition 315 Scientists, 2009. Expedition 315 Site C0001. In Kinoshita, M., Tobin, H., Ashi, J., Kimura, G., Lallemant, S., Screaton, E.J., Curewitz, D., Masago, H., Moe, K.T., and the Expedition 314/315/316 Scientists, Proc. IODP, 314/315/316: Washington, DC (Integrated Ocean Drilling Program Management International, Inc.). doi:10.2204/iodp.proc.314315316.123.2009

Folk, R.L., and Ward, W.C., 1957. Brazos River bar [Texas]: a study in the significance of grain size parameters. $J$. Sediment. Res., 27(1):3-26. http://jsedres.sepmonline.org/cgi/content/abstract/27/1/3

Friedman, G.M., 1958. Determination of sieve-size distribution from thin-section data for sedimentary petrological studies. J. Geol., 66(4):349-416. doi:10.1086/ 626525

Gamage, K., Screaton, E., Bekins, B., and Aiello, I., 2011. Permeability-porosity relationships of subduction zone 
sediments. Mar. Geol., 279(1-4):19-36. doi:10.1016/ j.margeo.2010.10.010

Golin, Y.L., Karyarin, V.E., Pospelov, B.S., and Sevedkin, V.I., 1992. Pore tortuosity estimates in porous media. Sov. Electrochem., 28:87-91.

Griffiths, J.C., 1967. Scientific Method in Analysis of Sediments: New York (McGraw-Hill). doi:10.1126/science.159.3812.295

Kim, J.-W., Bryant, W.R., Watkins, J.S., and Tieh, T.T., 1999. Electron microscopic observations of shale diagenesis, offshore Louisiana, USA, Gulf of Mexico. Geo-Mar. Lett., 18(3):234-240. doi:10.1007/s003670050073

Krumbein, W.C., 1935. Thin-section mechanical analysis of indurated sediments. J. Geol., 43(5):482-496. doi:10.1086/624330

Martínez-Nistal, A., Veniale, F., Setti, M., and Cotecchia, F., 1999. A scanning electron microscopy image processing method for quantifying fabric orientation of clay geomaterials. Appl. Clay Sci., 14(4):235-243. doi:10.1016/ S0169-1317(98)00055-6

Mitchell, J.K., 1993. Fundamentals of Soil Behavior (2nd ed.): New York (Wiley).

Moon, C.F., and Hurst, C.W., 1984. Fabrics of muds and shales: an overview. In Stow, D.A.V., and Piper, D.J.W. (Eds.), Fine-Grained Sediments: Deep-Water Processes and Facies. Geol. Soc. Spec. Publ., 15(1):579-593. doi:10.1144/GSL.SP.1984.015.01.36

Moore, G.F., Park, J.-O., Bangs, N.L., Gulick, S.P., Tobin, H.J., Nakamura, Y., Sato, S., Tsuji, T., Yoro, T., Tanaka, H., Uraki, S., Kido, Y., Sanada, Y., Kuramoto, S., and Taira, A., 2009. Structural and seismic stratigraphic framework of the NanTroSEIZE Stage 1 transect. In Kinoshita, M., Tobin, H., Ashi, J., Kimura, G., Lallemant, S., Screaton, E.J., Curewitz, D., Masago, H., Moe, K.T., and the Expedition 314/315/316 Scientists, Proc. IODP, 314/315/316: Washington, DC (Integrated Ocean
Drilling Program Management International, Inc.). doi:10.2204/iodp.proc.314315316.102.2009

Moore, J.C., and Vrolijk, P., 1992. Fluids in accretionary prisms. Rev. Geophys., 30(2):113-135. doi:10.1029/ 92RG00201

Neuzil, C.E., 1994. How permeable are clays and shales? Water Resour. Res., 30(2):145-150. doi:10.1029/ 93WR02930

Olsen, H.W., 1960. Hydraulic flow through saturated clay. Clays Clay Miner., 9(1)131-161. doi:10.1346/ CCMN.1960.0090108

Saffer, D.M., and Bekins, B.A., 2006. An evaluation of factors influencing pore pressure in accretionary complexes: implications for taper angle and wedge mechanics. J. Geophys. Res., [Solid Earth], 111(B4):B04101. doi:10.1029/2005JB003990

Sintubin, M., 1994. Clay fabrics in relation to the burial history of shales. Sedimentology, 41(6):1161-1169. doi:10.1111/j.1365-3091.1994.tb01447.x

van der Plas, L., 1962. Preliminary note on the granulometric analysis of sedimentary rocks. Sedimentology, 1(2):145-157. doi:10.1111/j.13653091.1962.tb00031.x

Yang, Y., and Aplin, A.C., 2007. Permeability and petrophysical properties of 30 natural mudstones. J. Geophys. Res., [Solid Earth], 112(B3):B03206. doi:10.1029/ 2005JB004243

Zaniewski, K., and Van Der Meer, J.J.M., 2005. Quantification of plasmic fabric through image analysis. Catena, 63(1):109-127. doi:10.1016/j.catena.2005.07.001

Initial receipt: 9 July 2010

Acceptance: 28 October 2011

Publication: 8 March 2012

MS 314315316-204 
Figure F1. Maps showing location of Site C0001 in the Nankai Trough accretionary prism. Sample positions are shown next to a generalized stratigraphic column, along with orientations (dip) of bedding from the "Expedition 315 Site C0001" chapter (Expedition 315 Scientists, 2009).

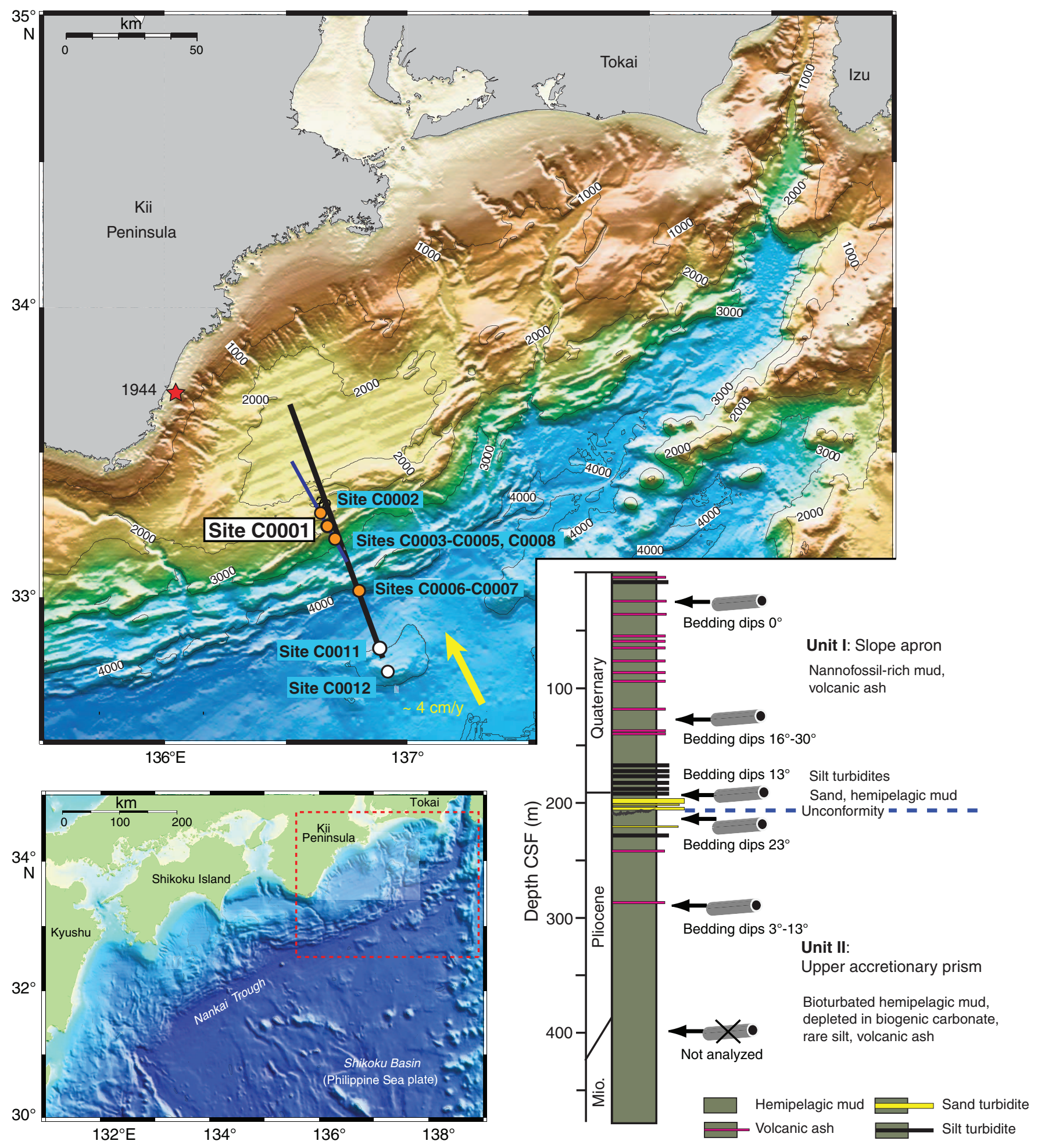


Figure F2. Schematic of constant-flow permeability testing system used for Expedition 315 samples at the University of Missouri (USA).

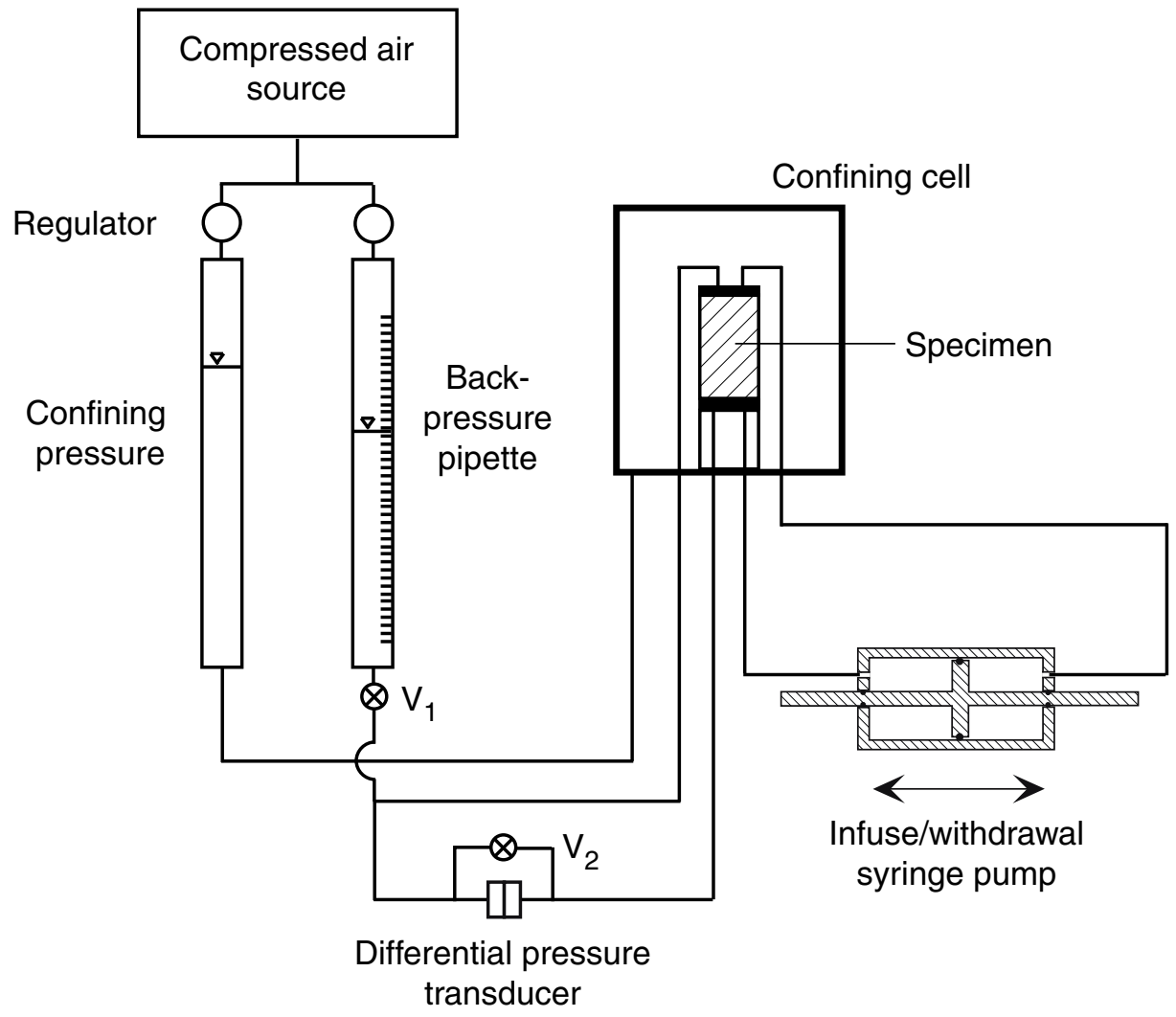


Figure F3. Plot of responses to transient head difference $\left(\Delta h_{\mathrm{s}}\right)$ during flow-through testing, Site C0001. $Q=$ volumetric flow rate, $K=$ hydraulic conductivity. Response measured using the differential pressure transducer for four redundant flow tests: Test Run 1 was conducted at volumetric flow rate of $+0.006 \mathrm{~cm}^{3} / \mathrm{min}$ (bottom to top), Test Run 2 was conducted at volumetric flow rate of $-0.006 \mathrm{~cm}^{3} / \mathrm{min}$ (top to bottom), Test Run 3 was conducted at volumetric flow rate of $+0.01 \mathrm{~cm}^{3} / \mathrm{min}$, Test Run 4 was conducted at volumetric flow rate of $-0.01 \mathrm{~cm}^{3} / \mathrm{min}$.

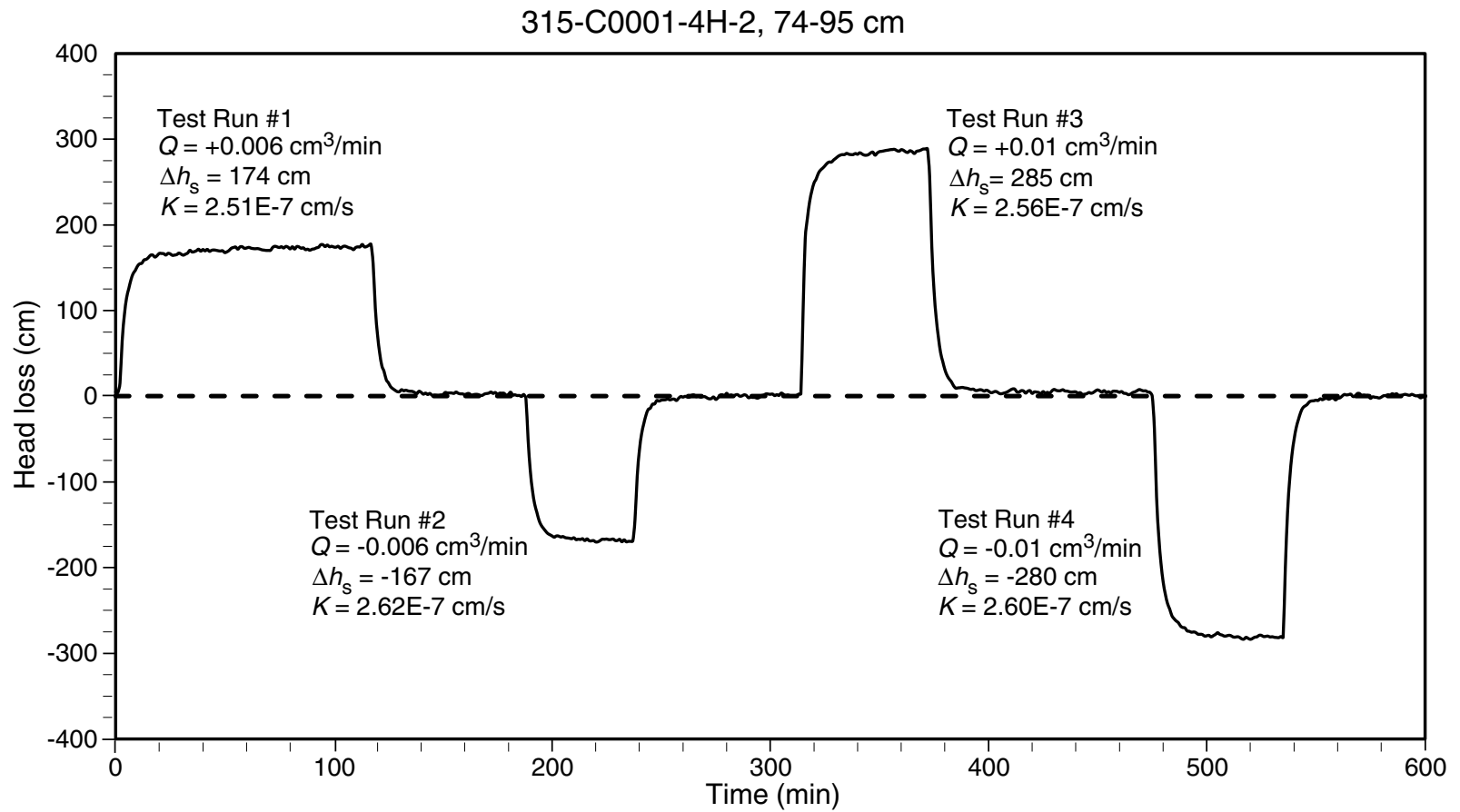


Figure F4. Diagram representing the horizontal and vertical section of core for imaging by environmental scanning electron microscope.

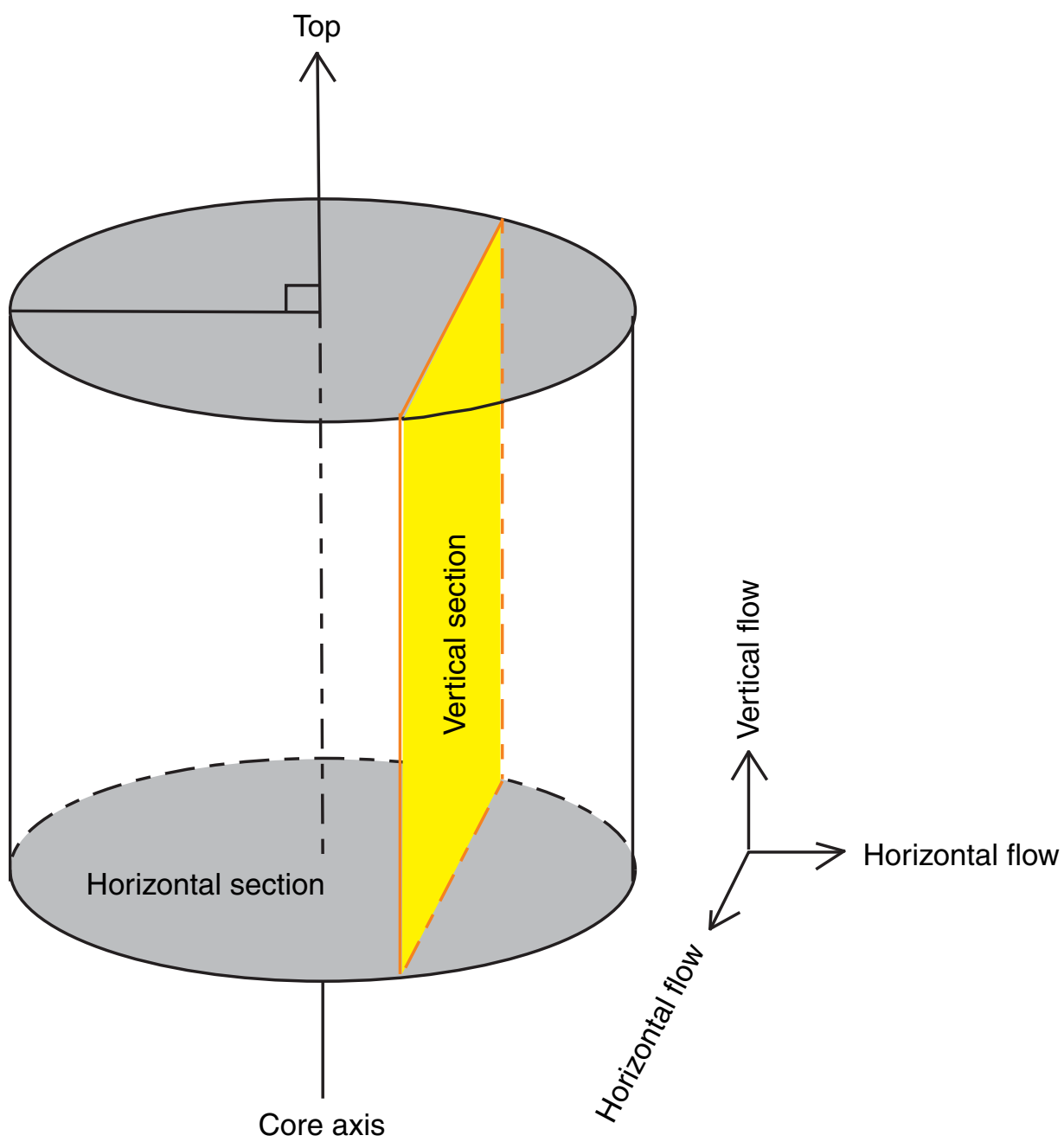


Figure F5. Illustrations of steps used during image analysis of microfabric (Sample 315-C0001F-10H-11, 15-35 $\mathrm{cm}$ ). A. Binary image obtained with ImageJ. B. Binary image (transparency $=60 \%$ ) overlapped on the original image in Photoshop. C. Binary image after particle separation using the eraser tool in Photoshop. D. Binary image after particles $<8$ pixels removed and holes filled.

A

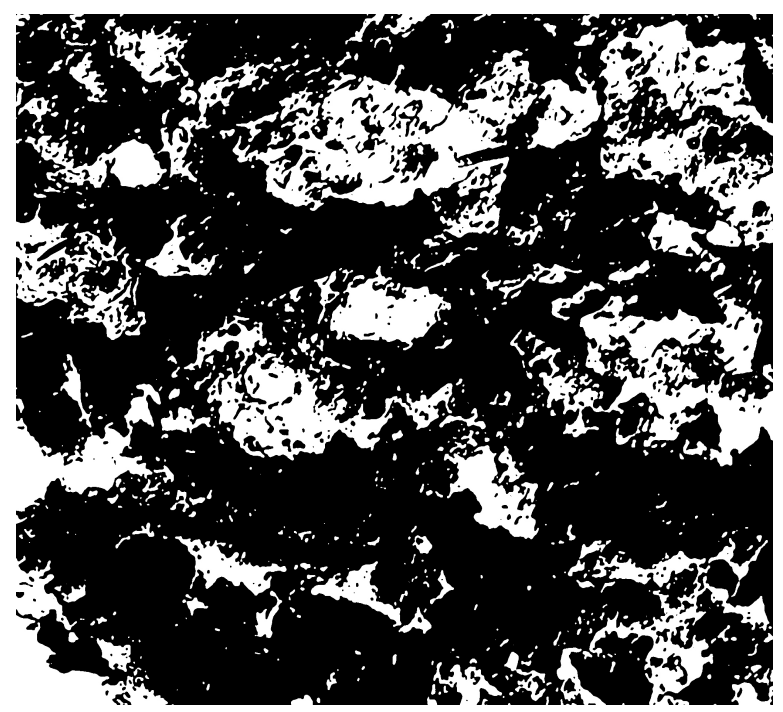

C

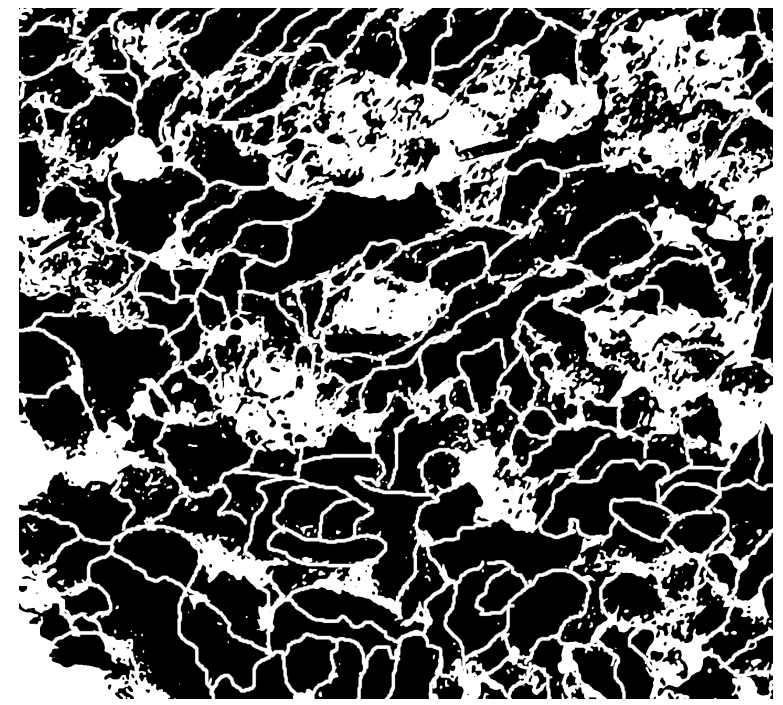

B

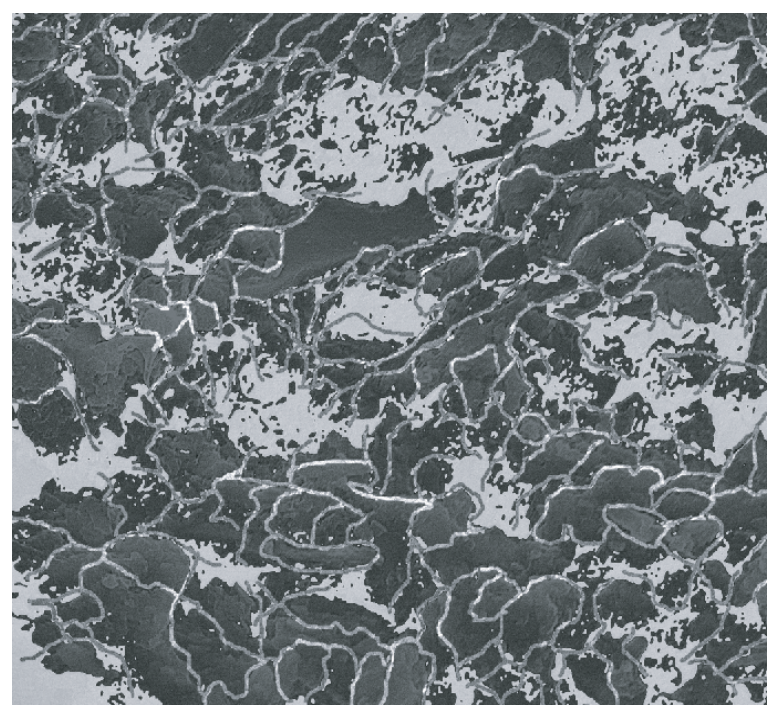

D

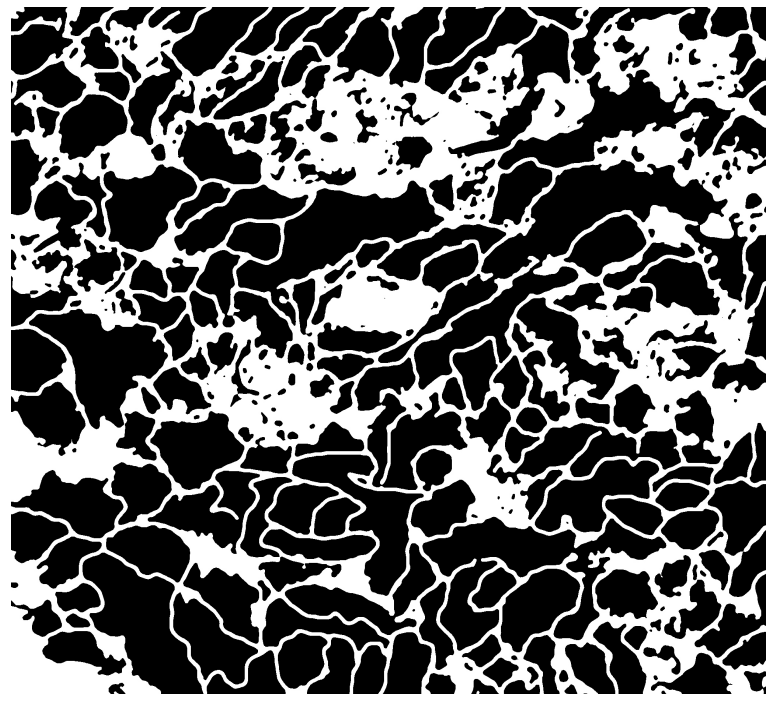

$50 \mu \mathrm{m}$ 
Figure F6. Average permeability values as a function of effective stress, Site C0001. A. Vertical permeability (relative to core axis). B. Horizontal permeability (relative to core axis).
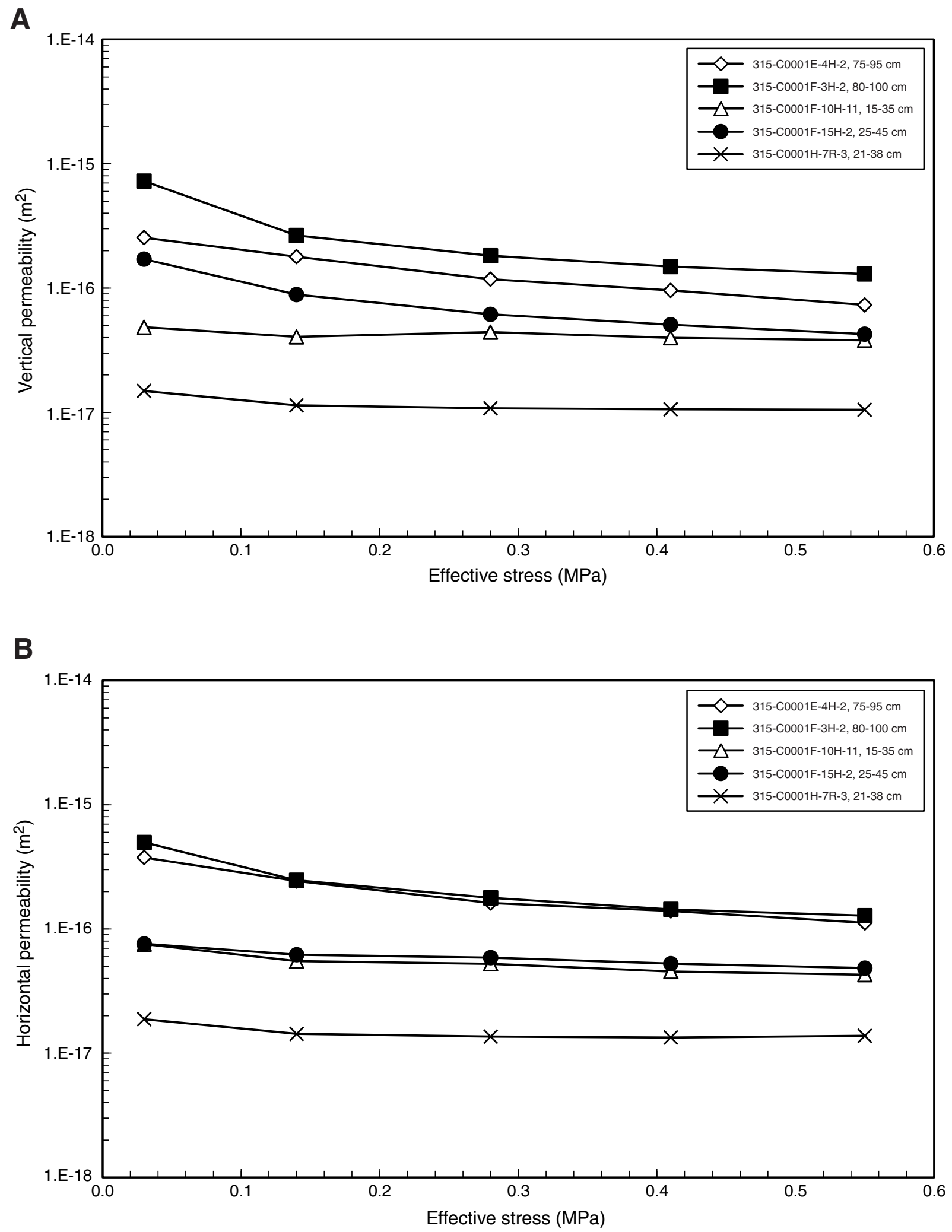
Figure F7. A. Vertical and horizontal permeability values with depth for samples collected from Site C0001. B. Anisotropy ratio for permeability (horizontal/vertical) as a function of depth, calculated at the highest testing value of effective stress $(0.55 \mathrm{MPa})$.

A

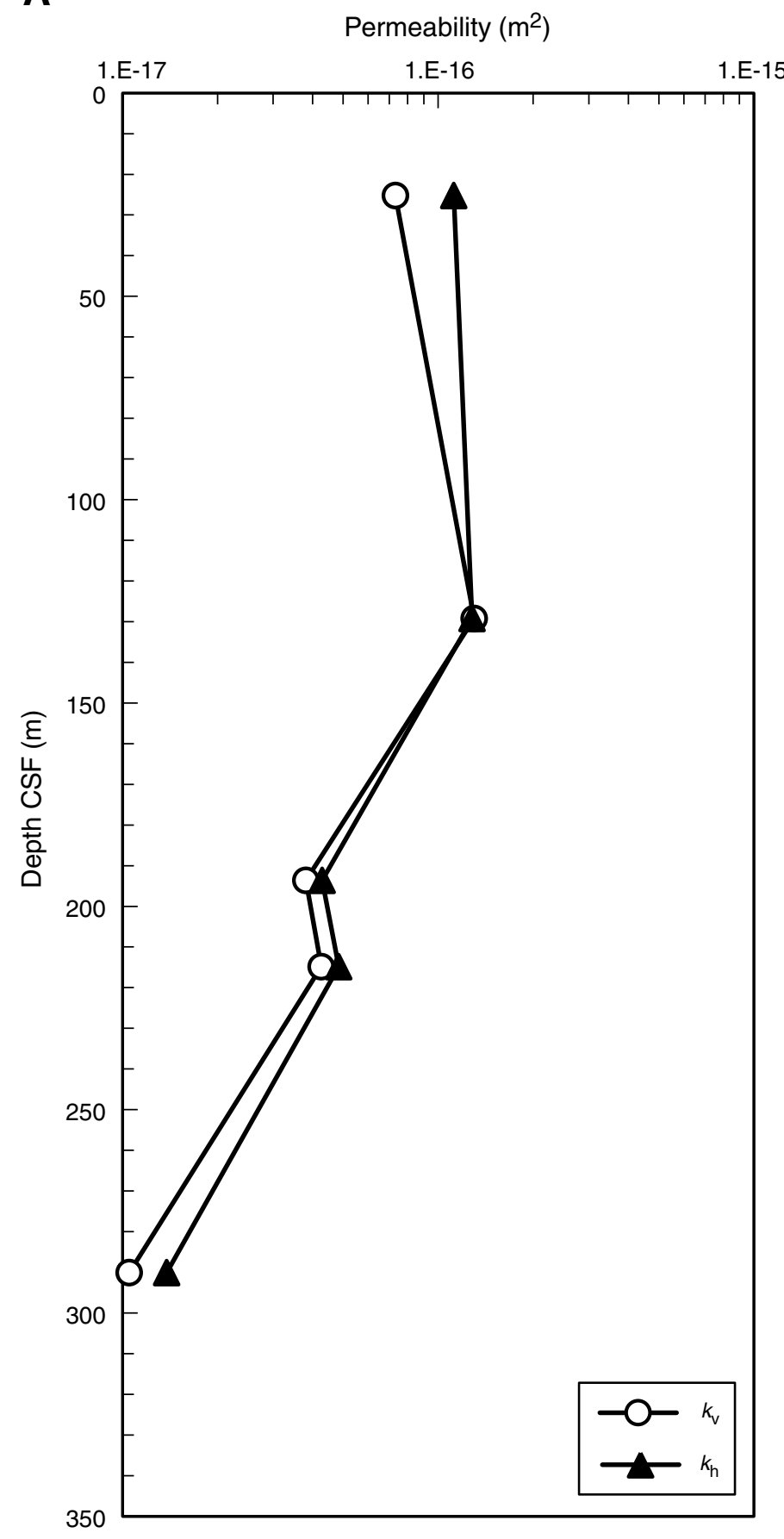

B

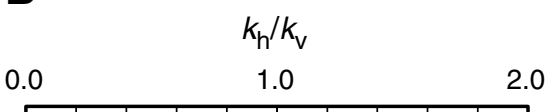

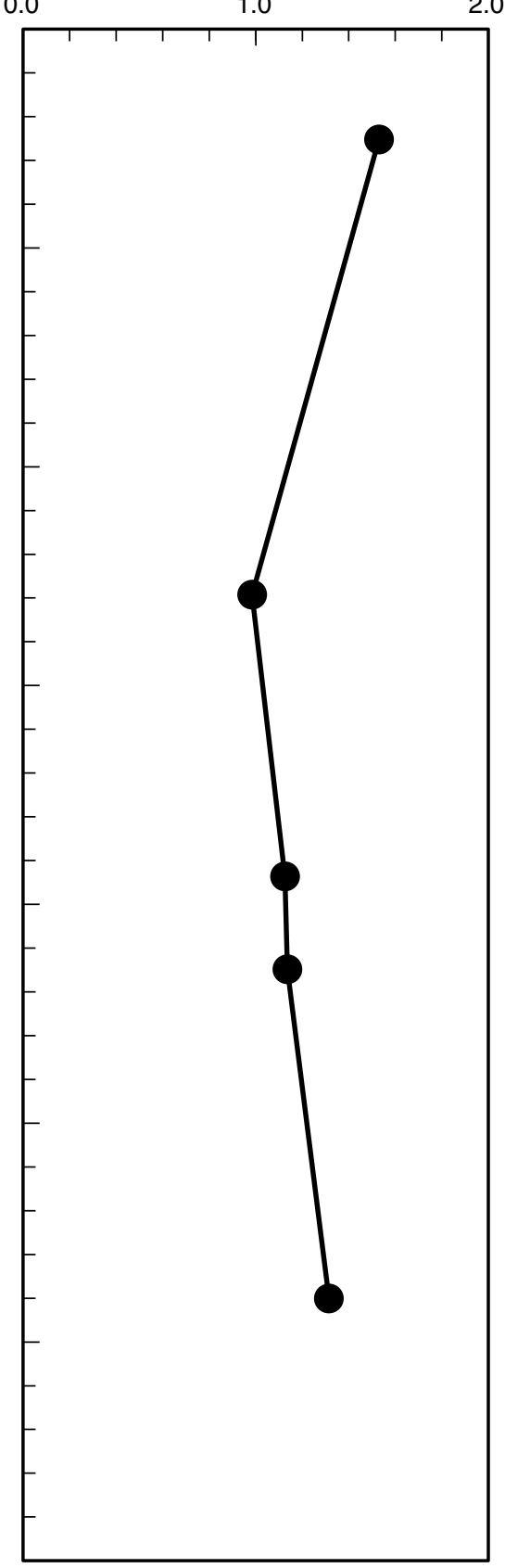


Figure F8. Anisotropy ratio for permeability (horizontal/vertical) as a function of applied effective stress, Site C0001.

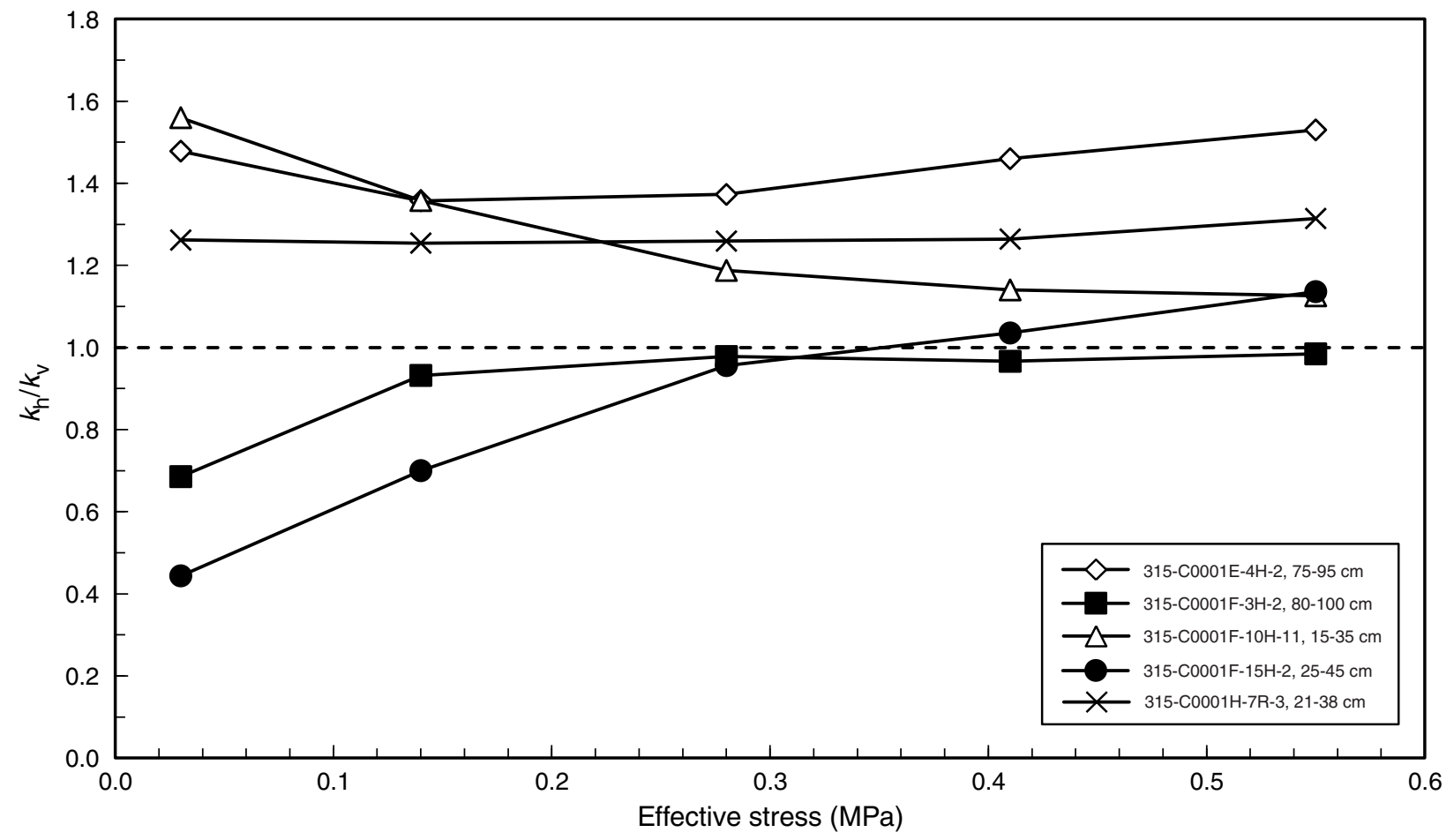


Figure F9. Relation between permeability and porosity at the highest testing value of effective stress (0.55 MPa), Site C0001. Porosity values determined from corresponding posttest water content measurements.

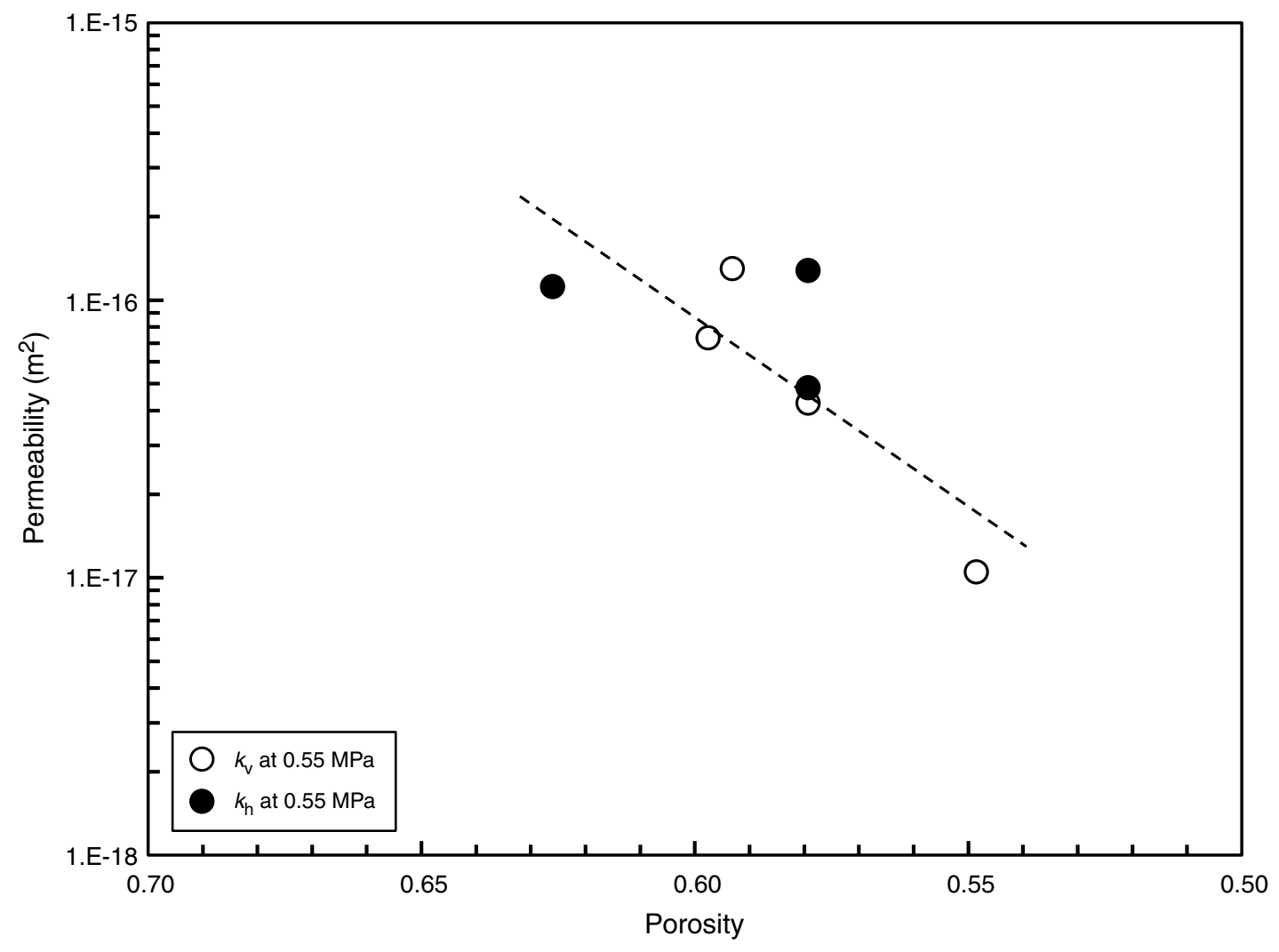


Figure F10. Rose diagrams showing orientation of apparent long axes of particles imaged by environmental scanning electron microscope on the horizontal and vertical sections relative to core axis, Site C0001. $n=$ number of grains counted; $d=$ standard deviation of grain orientation; $i=$ index of microfabric orientation.

Horizontal section

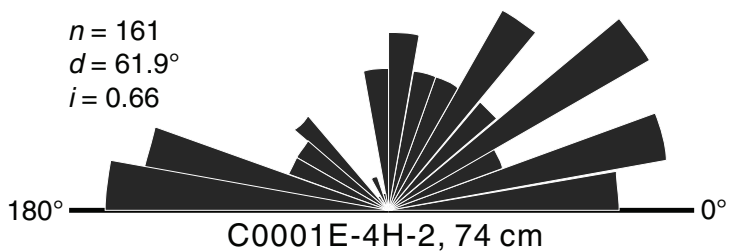

$\mathrm{C} 0001 \mathrm{E}-4 \mathrm{H}-2,74 \mathrm{~cm}$

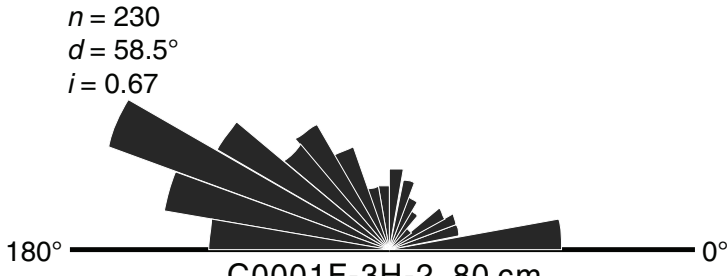

$\mathrm{C} 0001 \mathrm{~F}-3 \mathrm{H}-2,80 \mathrm{~cm}$

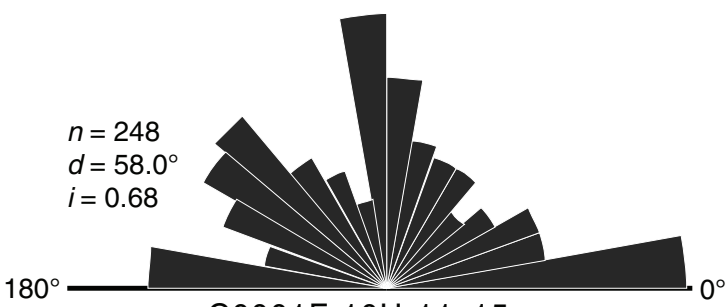

$\mathrm{C} 0001 \mathrm{~F}-10 \mathrm{H}-11,15 \mathrm{~cm}$
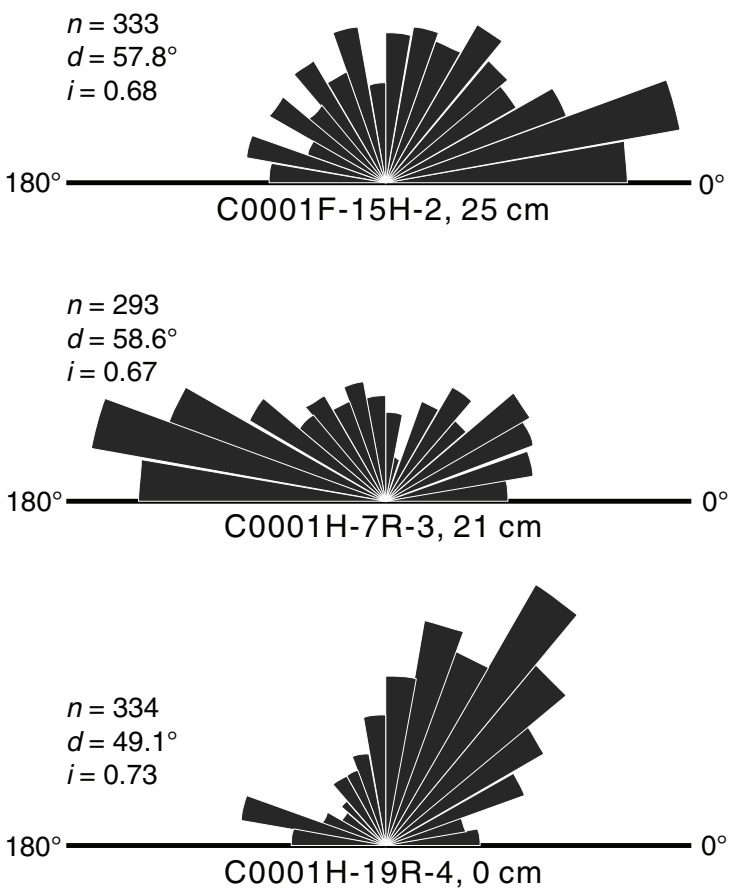

Vertical section
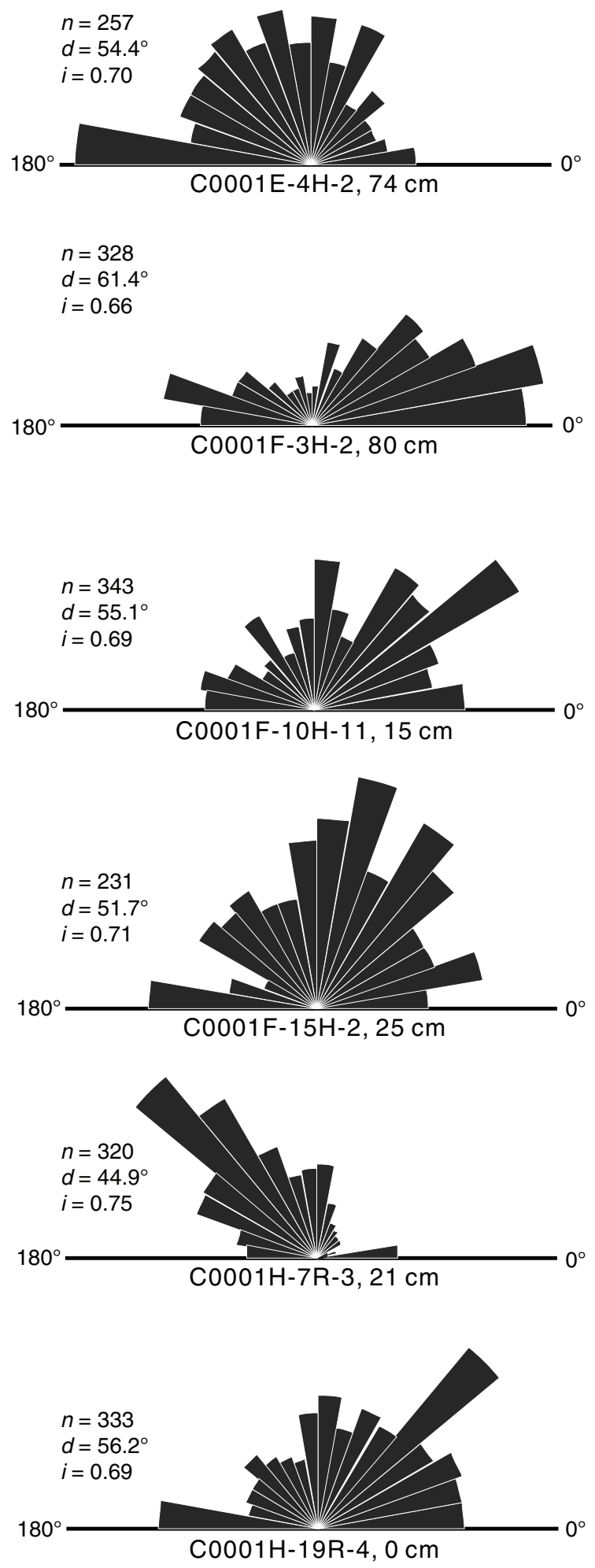
Figure F11. Cumulative frequency curves for apparent orientation of long axes of particles imaged by environmental scanning electron microscope on the horizontal and vertical sections relative to core axis, Site C0001.
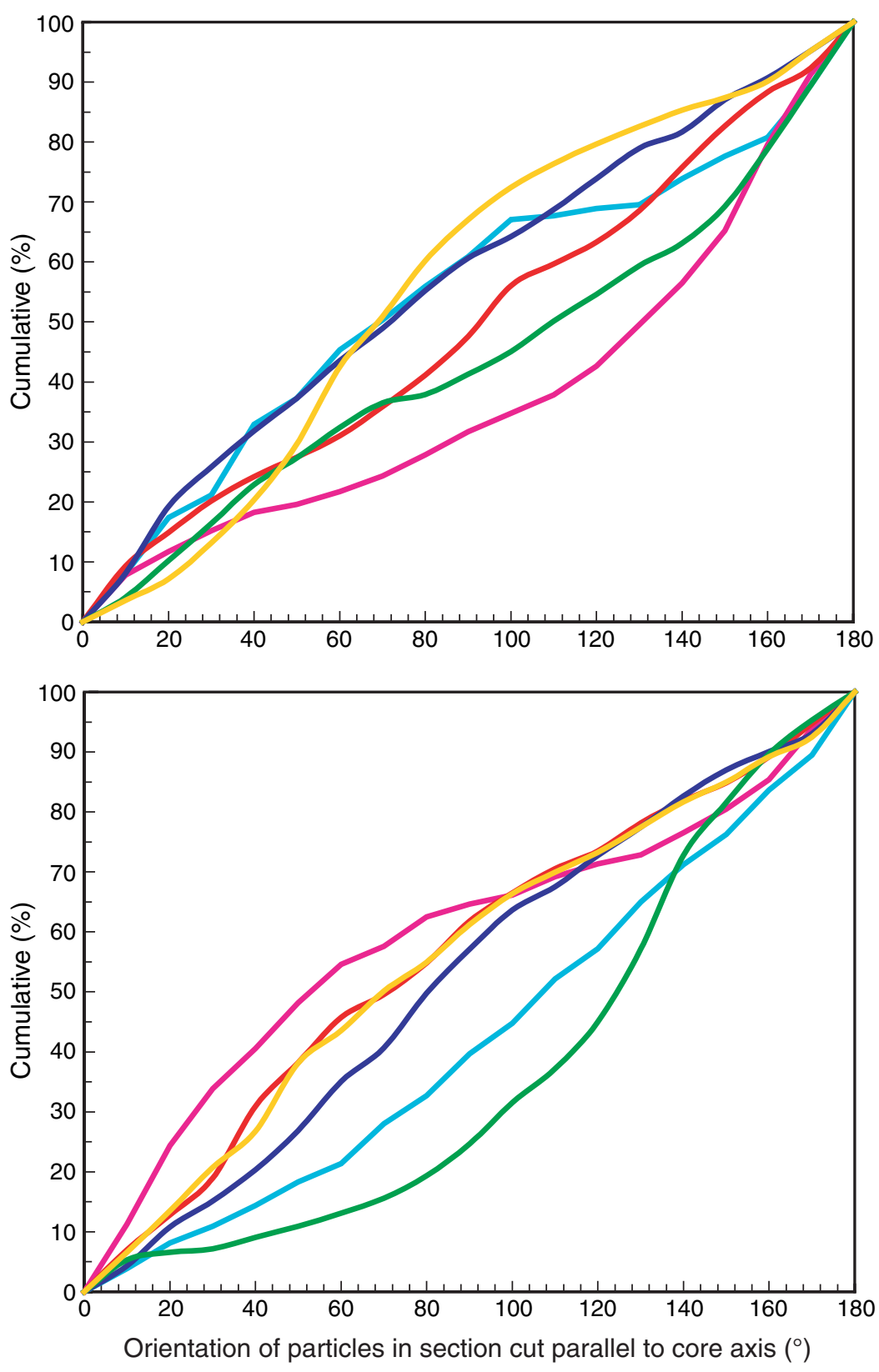

Sample

315-C0001E-4H-2, $74 \mathrm{~cm}$

Sample

315-C0001F-3H-2, $80 \mathrm{~cm}$

Sample

315- C0001F-10H-11, $15 \mathrm{~cm}$

Sample

315-C0001F-15H-2, $25 \mathrm{~cm}$

Sample

315-C0001H-7R-3, $21 \mathrm{~cm}$

Sample

315-C0001H-19R-4, $0 \mathrm{~cm}$ 
Table T1. Summary of permeability specimen properties, Site C0001.

\begin{tabular}{|c|c|c|c|c|c|c|c|c|c|c|c|c|}
\hline \multirow[b]{2}{*}{$\begin{array}{l}\text { Hole, core, section, } \\
\text { interval }(\mathrm{cm})\end{array}$} & \multirow[b]{2}{*}{$\begin{array}{l}\text { Orientation } \\
\text { to core axis }\end{array}$} & \multirow[b]{2}{*}{$\begin{array}{l}\text { Depth } \\
\text { (mbsf) }\end{array}$} & \multicolumn{3}{|c|}{ Atterberg limits } & \multirow[b]{2}{*}{$\begin{array}{c}\text { Initial } \\
\text { water } \\
\text { content }\end{array}$} & \multirow[b]{2}{*}{$\begin{array}{l}\text { Initial } \\
\text { porosity }\end{array}$} & \multirow[b]{2}{*}{$\begin{array}{l}\text { Initial } \\
\text { height } \\
(\mathrm{cm})\end{array}$} & \multirow[b]{2}{*}{$\begin{array}{l}\text { Initial } \\
\text { diameter } \\
(\mathrm{cm})\end{array}$} & \multirow[b]{2}{*}{$\begin{array}{c}\text { Skempton's } \\
B \text {-value }\end{array}$} & \multirow[b]{2}{*}{$\begin{array}{c}\text { Final } \\
\text { water } \\
\text { content }\end{array}$} & \multirow[b]{2}{*}{$\begin{array}{c}\text { Final } \\
\text { porosity }\end{array}$} \\
\hline & & & $\begin{array}{c}\text { Liquid } \\
\text { limit } \\
(\%)\end{array}$ & $\begin{array}{c}\text { Plastic } \\
\text { limit } \\
(\%)\end{array}$ & $\begin{array}{l}\text { Plasticity } \\
\text { index }\end{array}$ & & & & & & & \\
\hline \multicolumn{13}{|l|}{$315-$} \\
\hline C0001E-4H-2, 74-95 & Vertical & 25.21 & 79 & 36 & 43 & 0.69 & 0.65 & 5.3 & 3.9 & 1.00 & 0.55 & 0.60 \\
\hline C0001E-4H-2, 74-95 & Horizontal & 25.21 & 79 & 36 & 43 & 0.70 & 0.65 & 5.2 & 3.7 & 0.98 & 0.62 & 0.63 \\
\hline C0001F-3H-2, 80-100 & Vertical & 129.22 & 73 & 39 & 34 & 0.57 & 0.61 & 5.9 & 3.7 & 0.96 & 0.54 & 0.59 \\
\hline C0001F-3H-2, 80-100 & Horizontal & 129.22 & 73 & 39 & 34 & 0.55 & 0.60 & 5.5 & 3.4 & 0.93 & 0.51 & 0.58 \\
\hline C0001F-10H-11, 15-35 & Vertical & 193.61 & 71 & 35 & 36 & 0.46 & 0.56 & 5.8 & 4.1 & 0.98 & ND & ND \\
\hline C0001F-10H-11, 15-35 & Horizontal & 193.61 & 71 & 35 & 36 & 0.50 & 0.57 & 5.9 & 4.0 & 0.97 & ND & ND \\
\hline C0001F-15H-2, 25-45 & Vertical & 214.83 & 78 & 42 & 36 & 0.53 & 0.59 & 4.8 & 3.7 & 0.95 & 0.51 & 0.58 \\
\hline C0001F-15H-2, 25-45 & Horizontal & 214.83 & 78 & 42 & 36 & 0.50 & 0.57 & 4.7 & 3.7 & 0.95 & 0.51 & 0.58 \\
\hline C0001H-7R-3, 21-38 & Vertical & 290.06 & 72 & 25 & 47 & 0.48 & 0.56 & 4.4 & 3.9 & 0.97 & 0.45 & 0.55 \\
\hline C0001H-7R-3, 21-38 & Horizontal & 290.06 & 72 & 25 & 47 & 0.49 & 0.57 & 5.5 & 3.9 & 0.95 & ND & ND \\
\hline
\end{tabular}

Initial water content determined from specimen trimmings, reported value is average of two gravimetric measurements. Initial porosity calculated from initial water content assuming $100 \%$ pore water saturation and specific gravity of 2.70 . Final water content determined from post-test measurement after consolidation at $0.55 \mathrm{MPa}$ effective stress. Final porosity calculated from final water content assuming $100 \%$ pore water saturation and specific gravity of 2.70 . ND = not determined. 
Table T2. Summary of permeability testing results, Site C0001.

\begin{tabular}{|c|c|c|c|c|c|}
\hline $\begin{array}{l}\text { Hole, core, section, } \\
\text { interval }(\mathrm{cm})\end{array}$ & $\begin{array}{l}\text { Depth } \\
\text { (mbsf) }\end{array}$ & $\begin{array}{c}\text { Effective } \\
\text { stress } \\
(\mathrm{MPa})\end{array}$ & $\begin{array}{l}\left(k_{\mathrm{v}}\right)_{\mathrm{avg}} \\
\left(\mathrm{m}^{2}\right)\end{array}$ & $\begin{array}{l}\left(k_{\mathrm{h}}\right)_{\mathrm{avg}} \\
\left(\mathrm{m}^{2}\right)\end{array}$ & $k_{\mathrm{h}} / k_{\mathrm{v}}$ \\
\hline \multicolumn{6}{|l|}{ 315- } \\
\hline \multirow[t]{5}{*}{ C0001E-4H-2, 74-95 } & 25.21 & 0.03 & $2.55 \mathrm{E}-16$ & 3.77E-16 & 1.48 \\
\hline & & 0.14 & $1.79 \mathrm{E}-16$ & $2.43 \mathrm{E}-16$ & 1.36 \\
\hline & & 0.28 & $1.18 \mathrm{E}-16$ & $1.62 \mathrm{E}-16$ & 1.37 \\
\hline & & 0.41 & $9.59 \mathrm{E}-17$ & $1.40 \mathrm{E}-16$ & 1.46 \\
\hline & & 0.55 & $7.32 \mathrm{E}-17$ & $1.12 \mathrm{E}-16$ & 1.53 \\
\hline \multirow[t]{5}{*}{ C0001F-3H-2, 80-100 } & 129.22 & 0.03 & $7.25 \mathrm{E}-16$ & $4.97 \mathrm{E}-16$ & 0.69 \\
\hline & & 0.14 & $2.65 \mathrm{E}-16$ & $2.47 \mathrm{E}-16$ & 0.93 \\
\hline & & 0.28 & $1.82 \mathrm{E}-16$ & $1.78 \mathrm{E}-16$ & 0.98 \\
\hline & & 0.41 & $1.49 \mathrm{E}-16$ & $1.44 \mathrm{E}-16$ & 0.97 \\
\hline & & 0.55 & $1.30 \mathrm{E}-16$ & $1.28 \mathrm{E}-16$ & 0.98 \\
\hline \multirow[t]{5}{*}{$\mathrm{C} 0001 \mathrm{~F}-10 \mathrm{H}-11,15-35$} & 193.61 & 0.03 & $4.84 \mathrm{E}-17$ & $7.55 \mathrm{E}-17$ & 1.56 \\
\hline & & 0.14 & $4.05 \mathrm{E}-17$ & $5.50 \mathrm{E}-17$ & 1.36 \\
\hline & & 0.28 & $4.42 \mathrm{E}-17$ & $5.25 \mathrm{E}-17$ & 1.19 \\
\hline & & 0.41 & $3.99 \mathrm{E}-17$ & $4.55 \mathrm{E}-17$ & 1.14 \\
\hline & & 0.55 & $3.81 \mathrm{E}-17$ & $4.29 \mathrm{E}-17$ & 1.13 \\
\hline \multirow[t]{5}{*}{ C0001F-15H-2, 25-45 } & 214.83 & 0.03 & $1.71 \mathrm{E}-16$ & $7.59 \mathrm{E}-17$ & 0.44 \\
\hline & & 0.14 & $8.87 \mathrm{E}-17$ & $6.21 \mathrm{E}-17$ & 0.70 \\
\hline & & 0.28 & $6.15 \mathrm{E}-17$ & $5.88 \mathrm{E}-17$ & 0.96 \\
\hline & & 0.41 & $5.08 \mathrm{E}-17$ & $5.26 \mathrm{E}-17$ & 1.04 \\
\hline & & 0.55 & $4.26 \mathrm{E}-17$ & $4.84 \mathrm{E}-17$ & 1.14 \\
\hline \multirow[t]{5}{*}{ C0001H-7R-3, 21-38 } & 290.06 & 0.03 & $1.49 \mathrm{E}-17$ & $1.88 \mathrm{E}-17$ & 1.26 \\
\hline & & 0.14 & $1.14 \mathrm{E}-17$ & $1.43 \mathrm{E}-17$ & 1.25 \\
\hline & & 0.28 & $1.08 \mathrm{E}-17$ & $1.36 \mathrm{E}-17$ & 1.26 \\
\hline & & 0.41 & $1.06 \mathrm{E}-17$ & $1.34 \mathrm{E}-17$ & 1.26 \\
\hline & & 0.55 & $1.05 \mathrm{E}-17$ & $1.38 \mathrm{E}-17$ & 1.31 \\
\hline
\end{tabular}


Table T3. Results of fabric analyses by statistical calculation, Site C0001.

\begin{tabular}{clcccc}
\hline Section & $\begin{array}{c}\text { Hole, core, section, } \\
\text { interval }(\mathrm{cm})\end{array}$ & $\begin{array}{c}\text { Grains } \\
\text { of count }\end{array}$ & $\begin{array}{c}\text { Slope } \\
\text { or tan }^{-1}\end{array}$ & $\begin{array}{c}\text { Degree of } \\
\text { orientation }\left(^{\circ}\right)\end{array}$ & $\begin{array}{c}\text { Index of } \\
\text { orientation }\end{array}$ \\
\hline \multirow{5}{*}{ Horizontal } & $\begin{array}{c}\text { 315- } \\
\text { C0001E-4H-2, 74 }\end{array}$ & 161 & 0.531928 .0 & 61.9 & 0.14 \\
& C0001F-3H-2, 80 & 230 & 0.529727 .9 & 58.5 & 0.19 \\
& C0001F-10H-11, 15 & 248 & 0.535128 .2 & 58.0 & 0.20 \\
& C0001F-15H-2, 25 & 333 & 0.549628 .8 & 57.8 & 0.21 \\
& C0001H-7R-3, 21 & 293 & 0.549528 .8 & 58.6 & 0.20 \\
& C0001H-19R-4, 0 & 334 & 0.570129 .7 & 49.1 & 0.32 \\
& C0001E-4H-2, 74 & 257 & 0.552328 .9 & 54.4 & 0.25 \\
& C0001F-3H-2, 80 & 328 & 0.538528 .3 & 61.4 & 0.15 \\
& C0001F-10H-11, 15 & 343 & 0.552628 .9 & 55.1 & 0.24 \\
& C0001F-15H-2, 25 & 231 & 0.557529 .2 & 51.7 & 0.28 \\
& C0001H-7R-3, 21 & 320 & 0.562529 .4 & 44.9 & 0.38 \\
& C0001H-19R-4, 0 & 333 & 0.540228 .4 & 56.2 & 0.22 \\
\hline
\end{tabular}

Slope is the slope of particle orientation frequency curve; slope $=[95-5] /\left[\theta_{95}-\theta_{5}\right]$. 
Figure AF1. Hydraulic gradient as a function of discharge velocity (Sample 315-C0001E-4H-2, 74-95 cm, vertical).

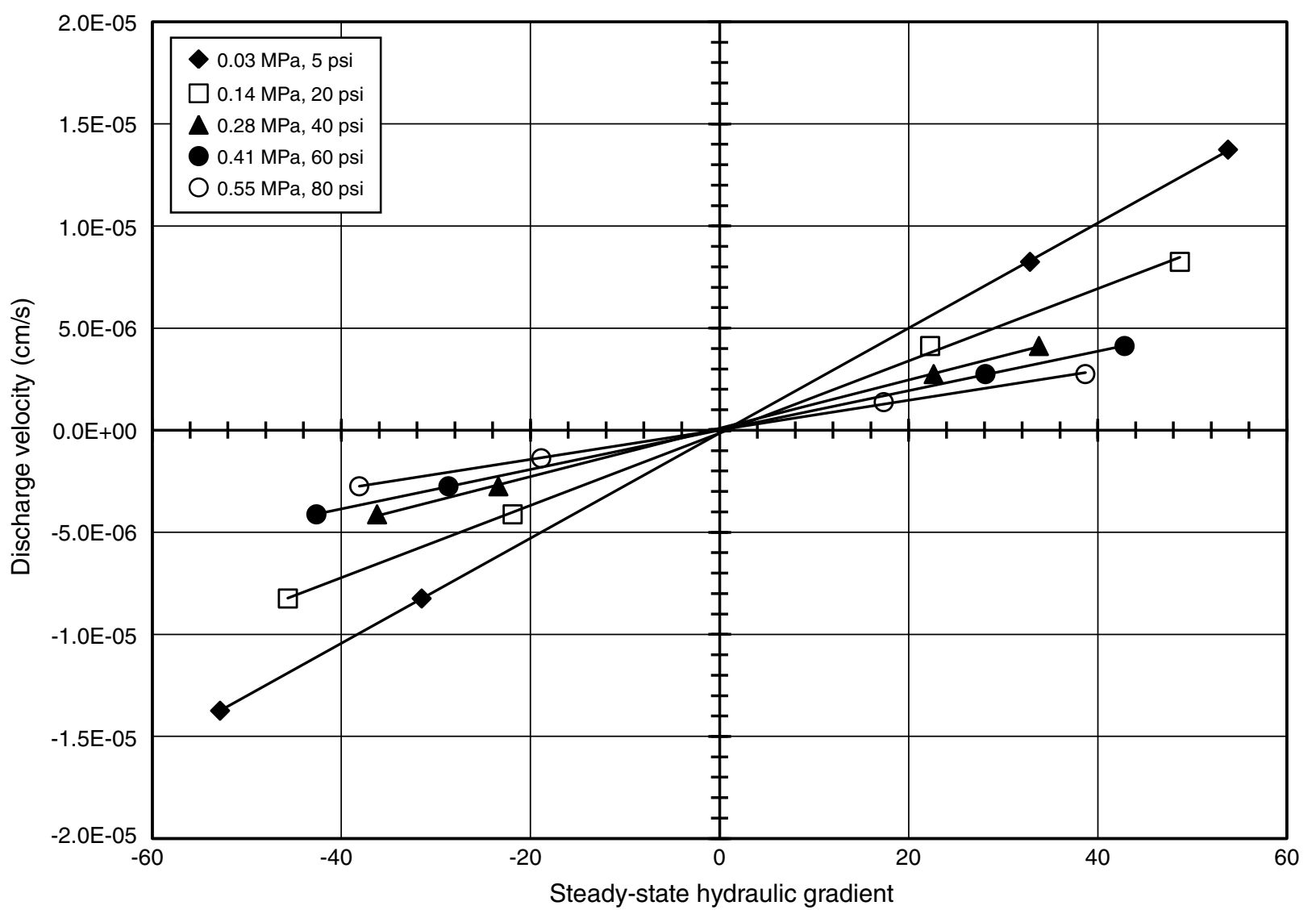


Figure AF2. Hydraulic gradient as a function of discharge velocity (Sample 315-C0001E-4H-2, 74-95 cm, horizontal).

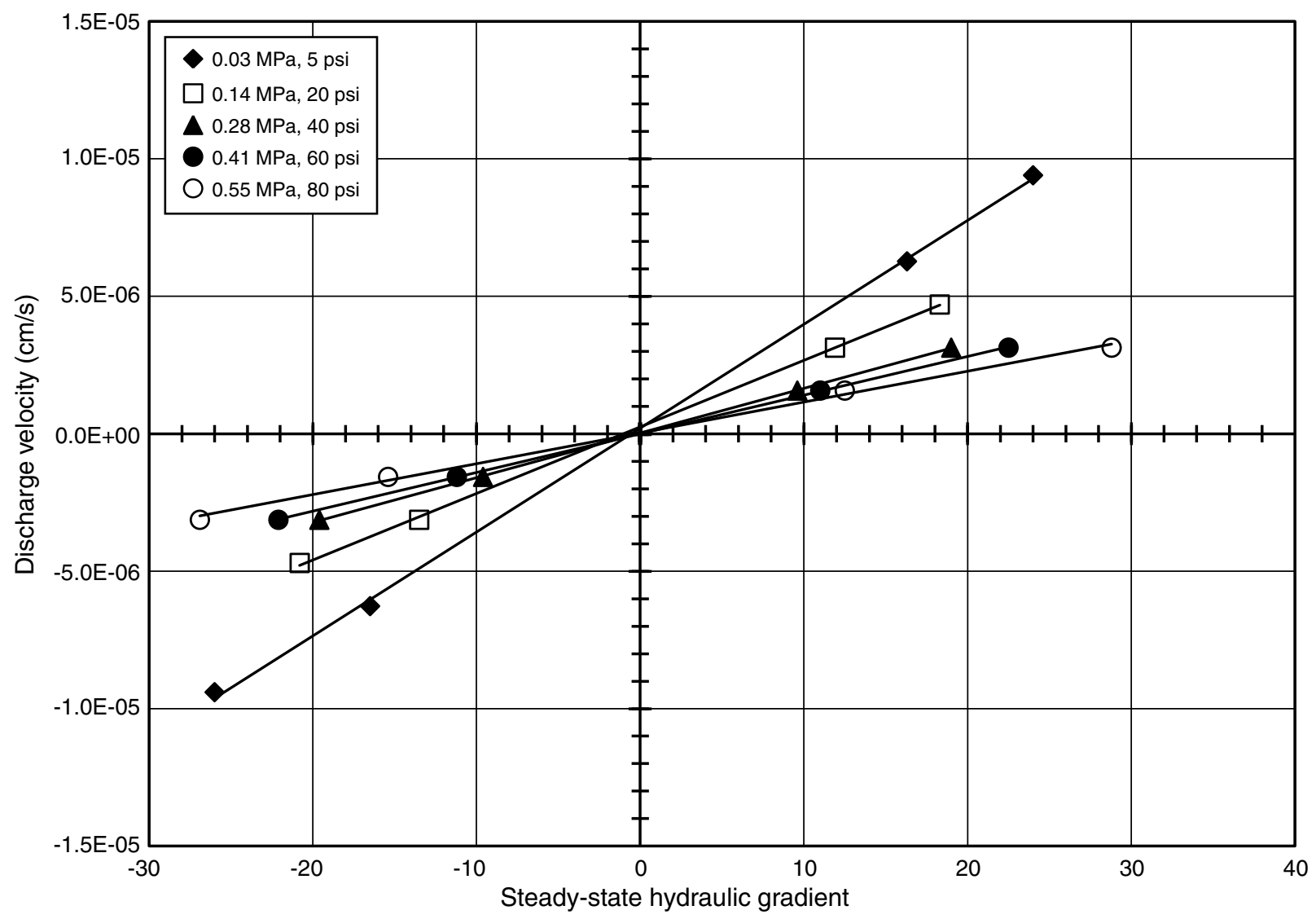


Figure AF3. Hydraulic gradient as a function of discharge velocity (Sample 315-C0001F-3H-2, 80-100 cm, vertical).

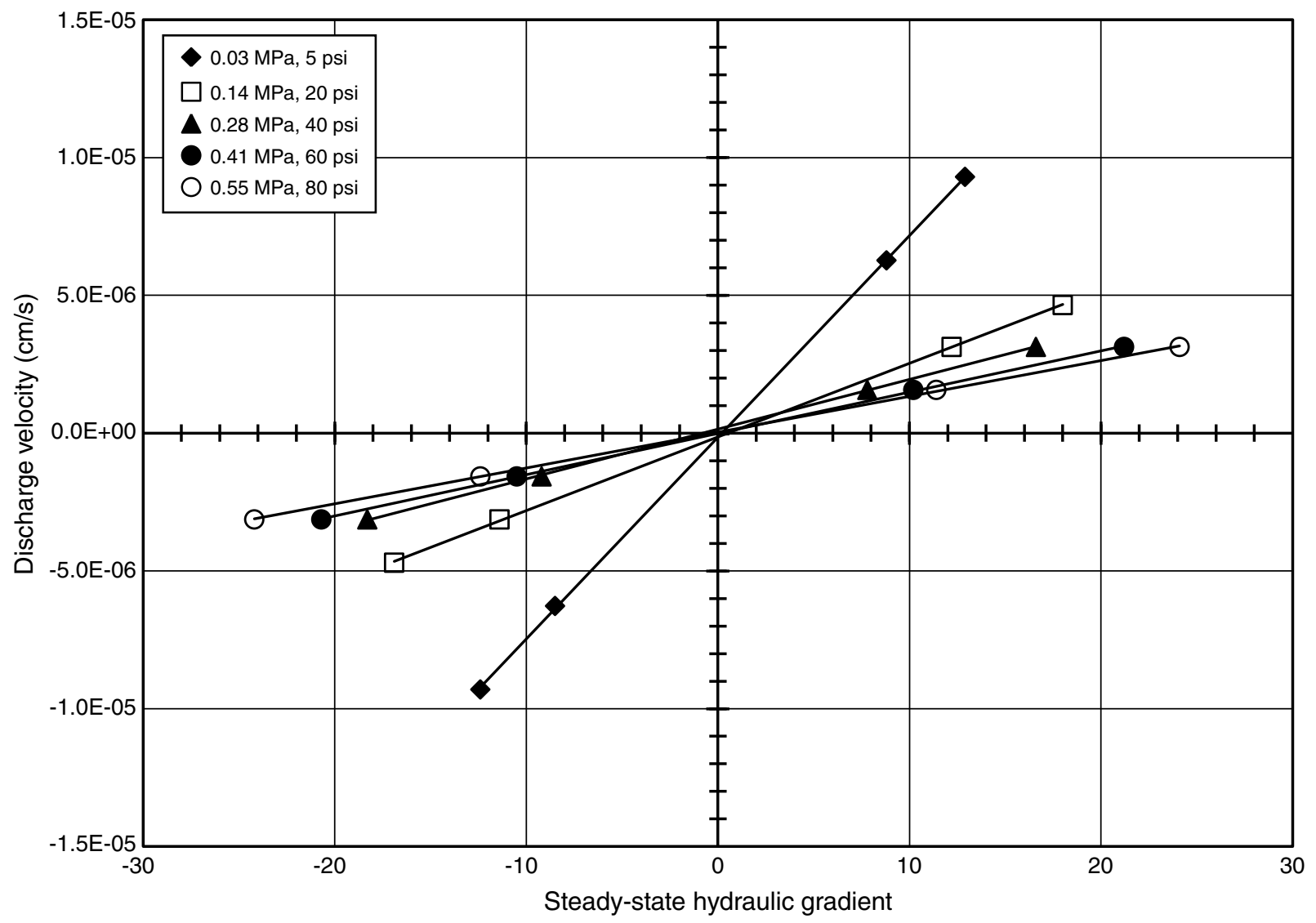


Figure AF4. Hydraulic gradient as a function of discharge velocity (Sample 315-C0001F-3H-2, 80-100 cm, horizontal).

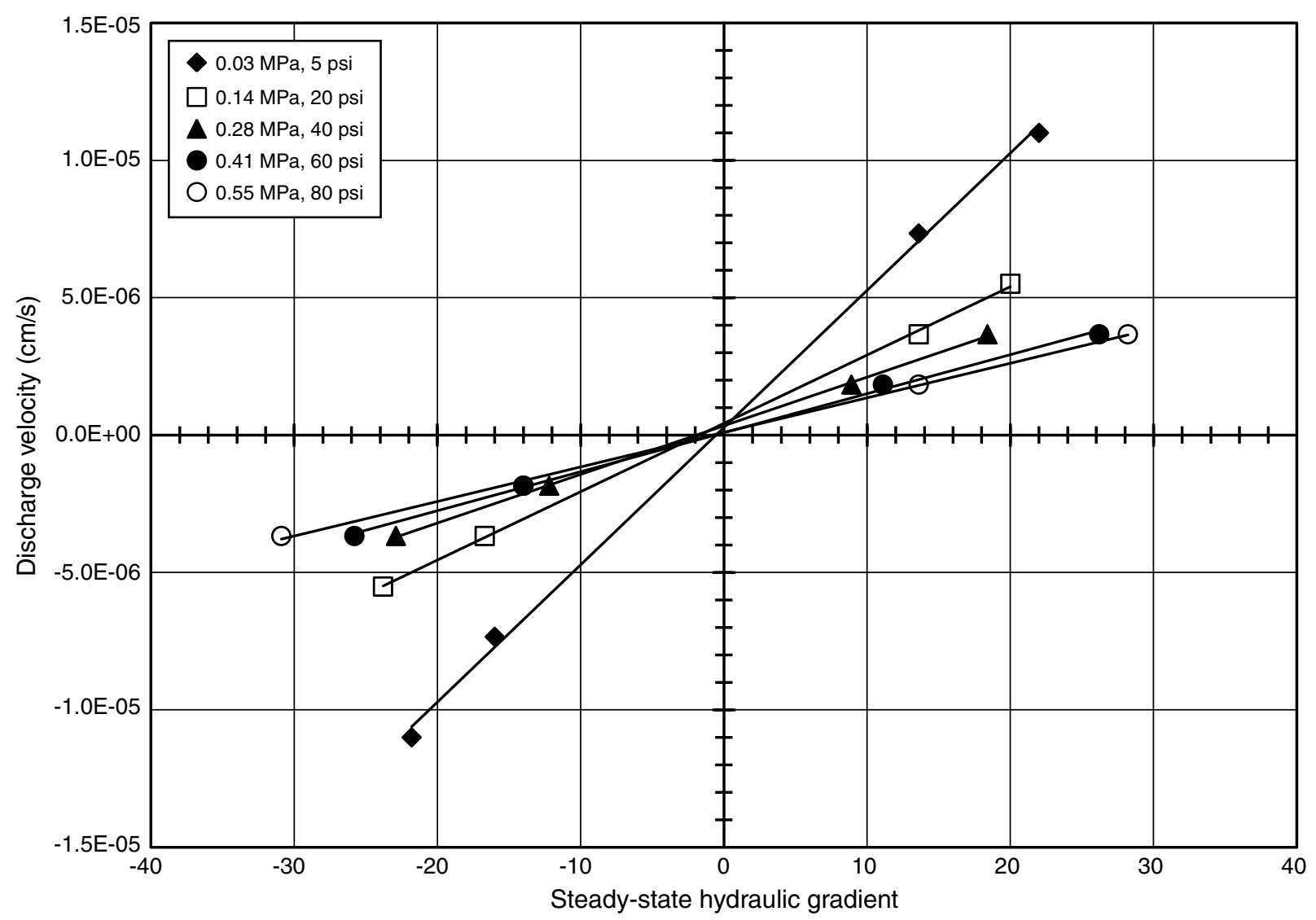


Figure AF5. Hydraulic gradient as a function of discharge velocity (Sample 315-C0001F-10H-11, 15-35 cm, vertical).

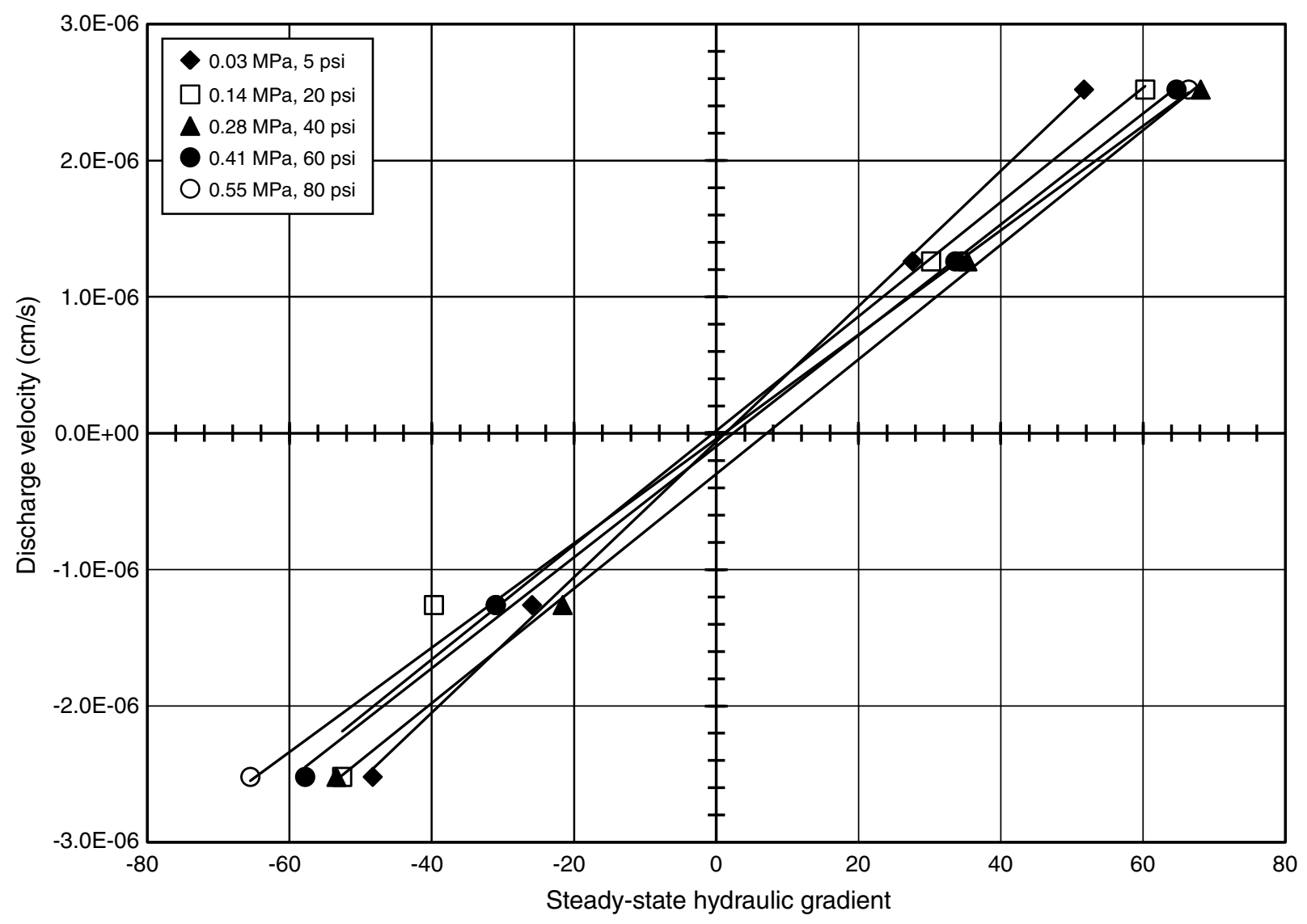


Figure AF6. Hydraulic gradient as a function of discharge velocity (Sample 315-C0001F-10H-11, 15-35 cm, horizontal).

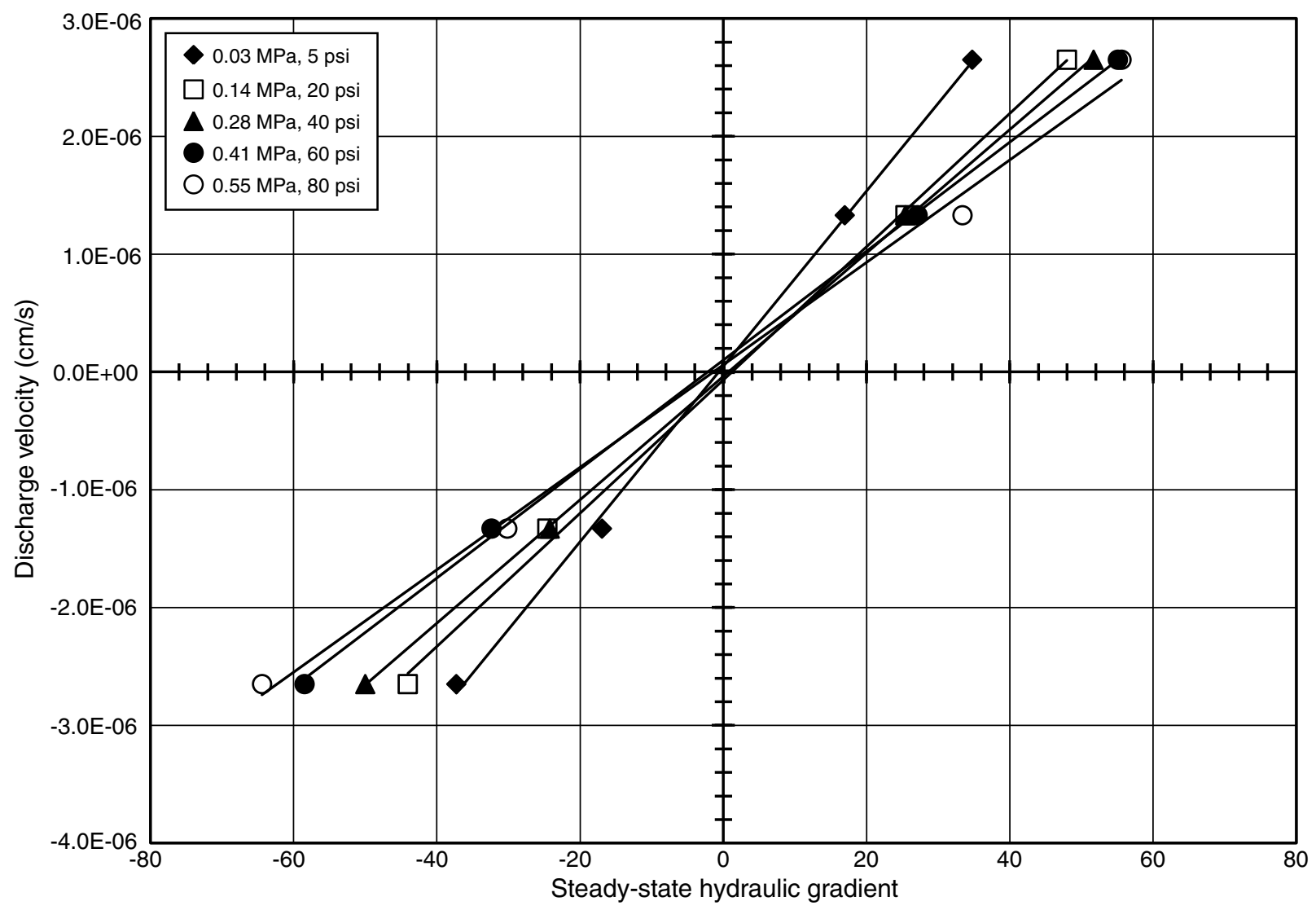


Figure AF7. Hydraulic gradient as a function of discharge velocity (Sample 315-C0001F-15H-2, 25-45 cm, vertical).

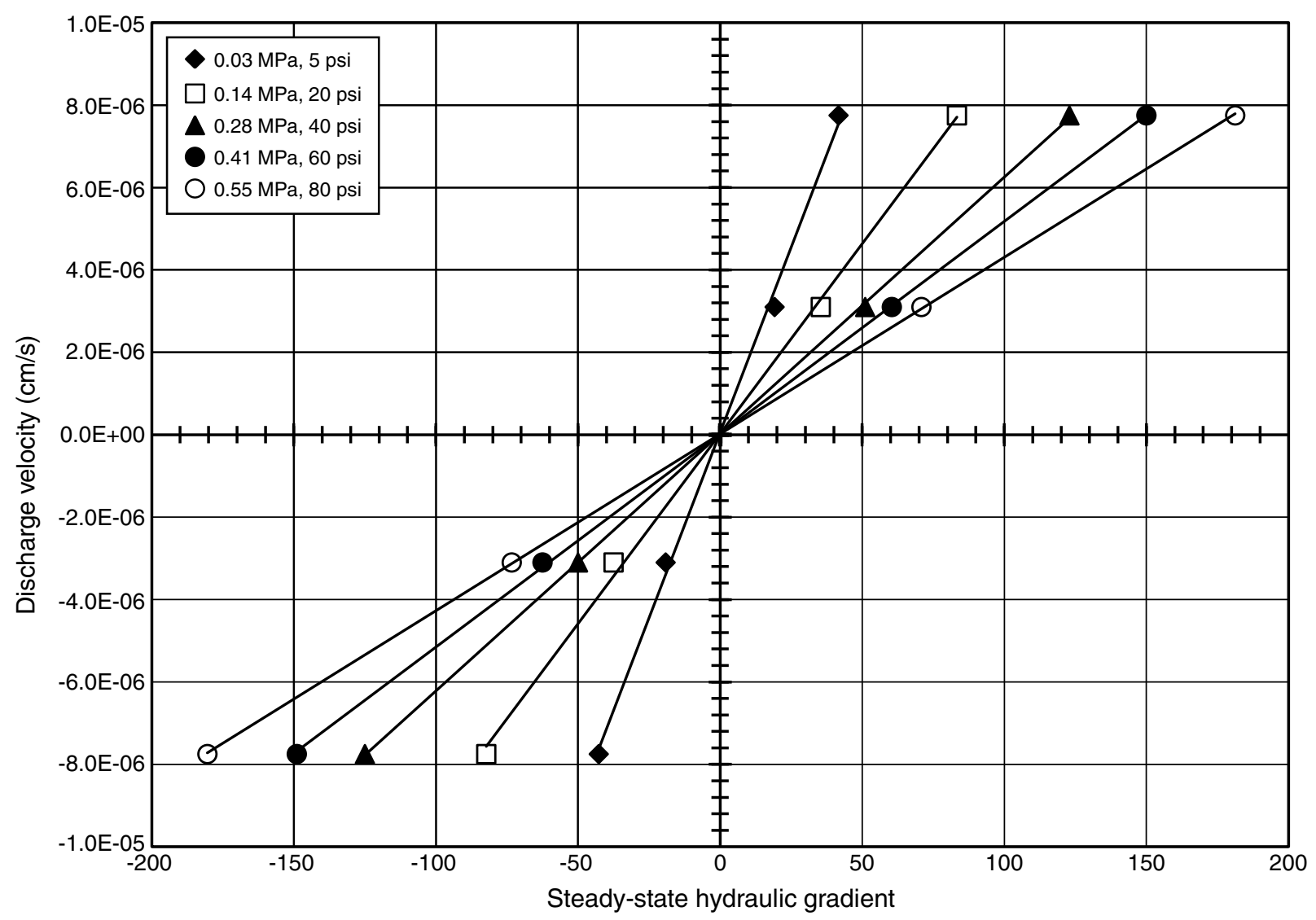


Figure AF8. Hydraulic gradient as a function of discharge velocity (Sample 315-C0001F-15H-2, 25-45 cm, horizontal).

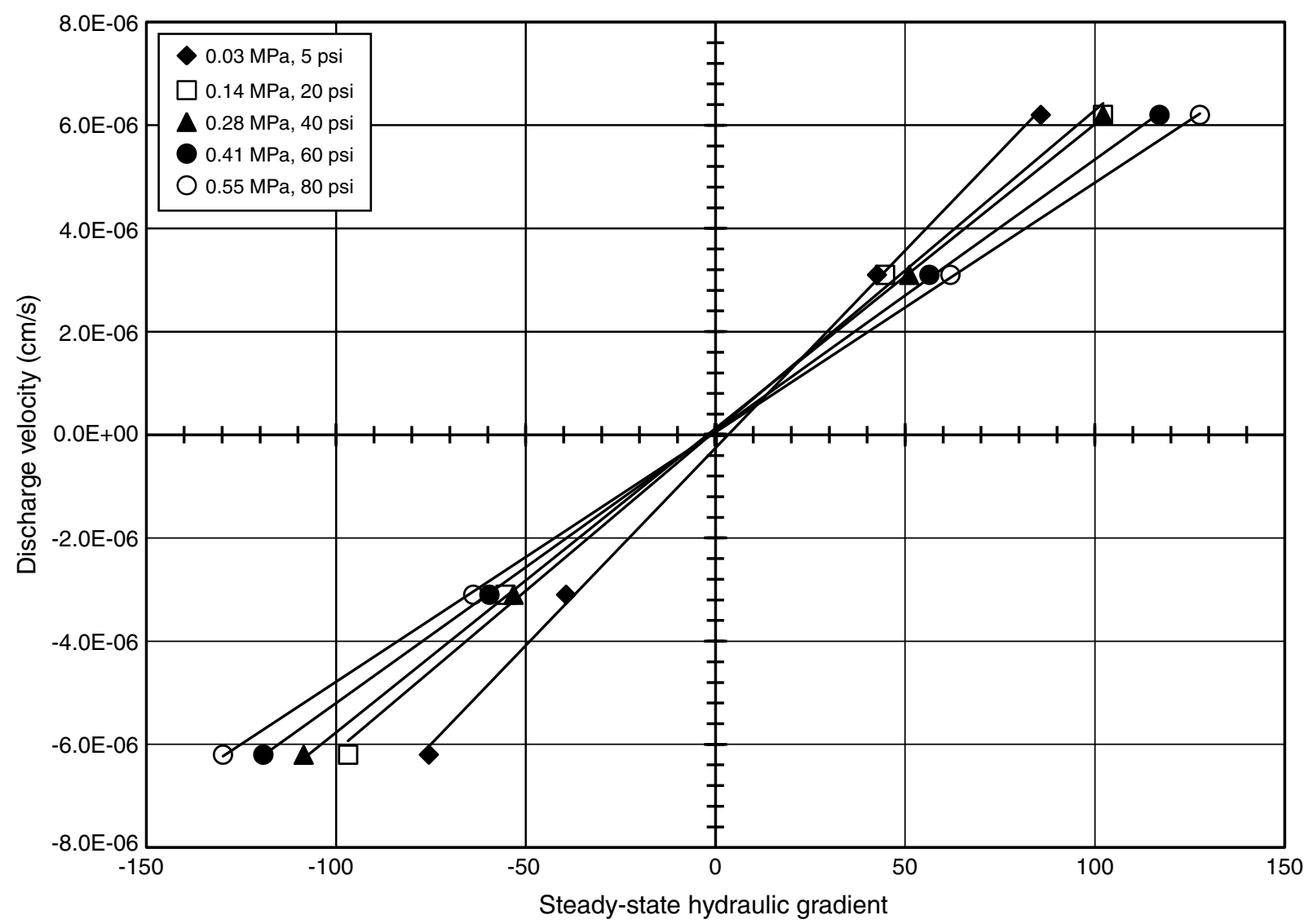


Figure AF9. Hydraulic gradient as a function of discharge velocity (Sample 315-C0001H-7R-3, 21-38 cm, vertical).

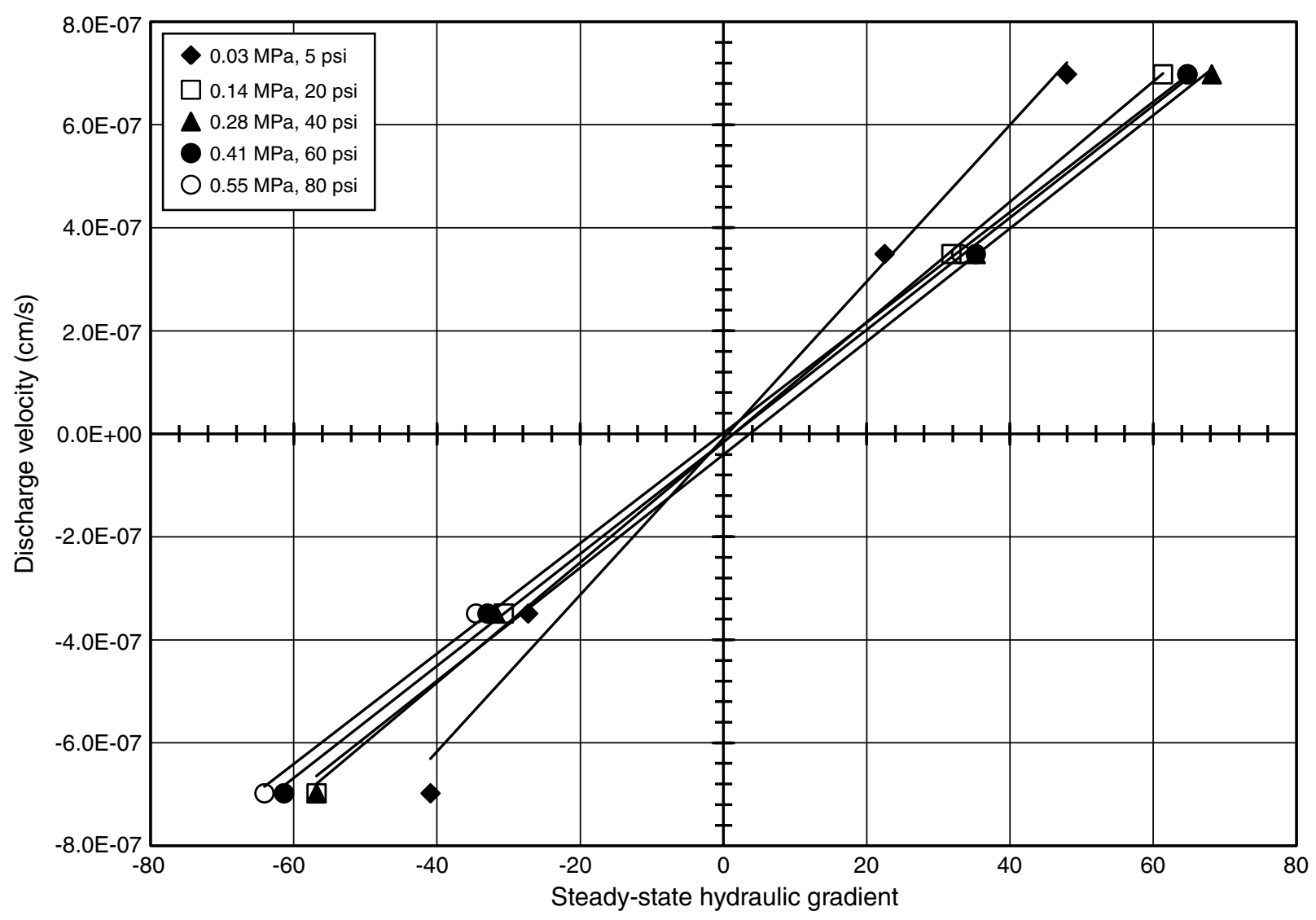


Figure AF10. Hydraulic gradient as a function of discharge velocity (Sample 315-C0001H-7R-3, 21-38 cm, horizontal).

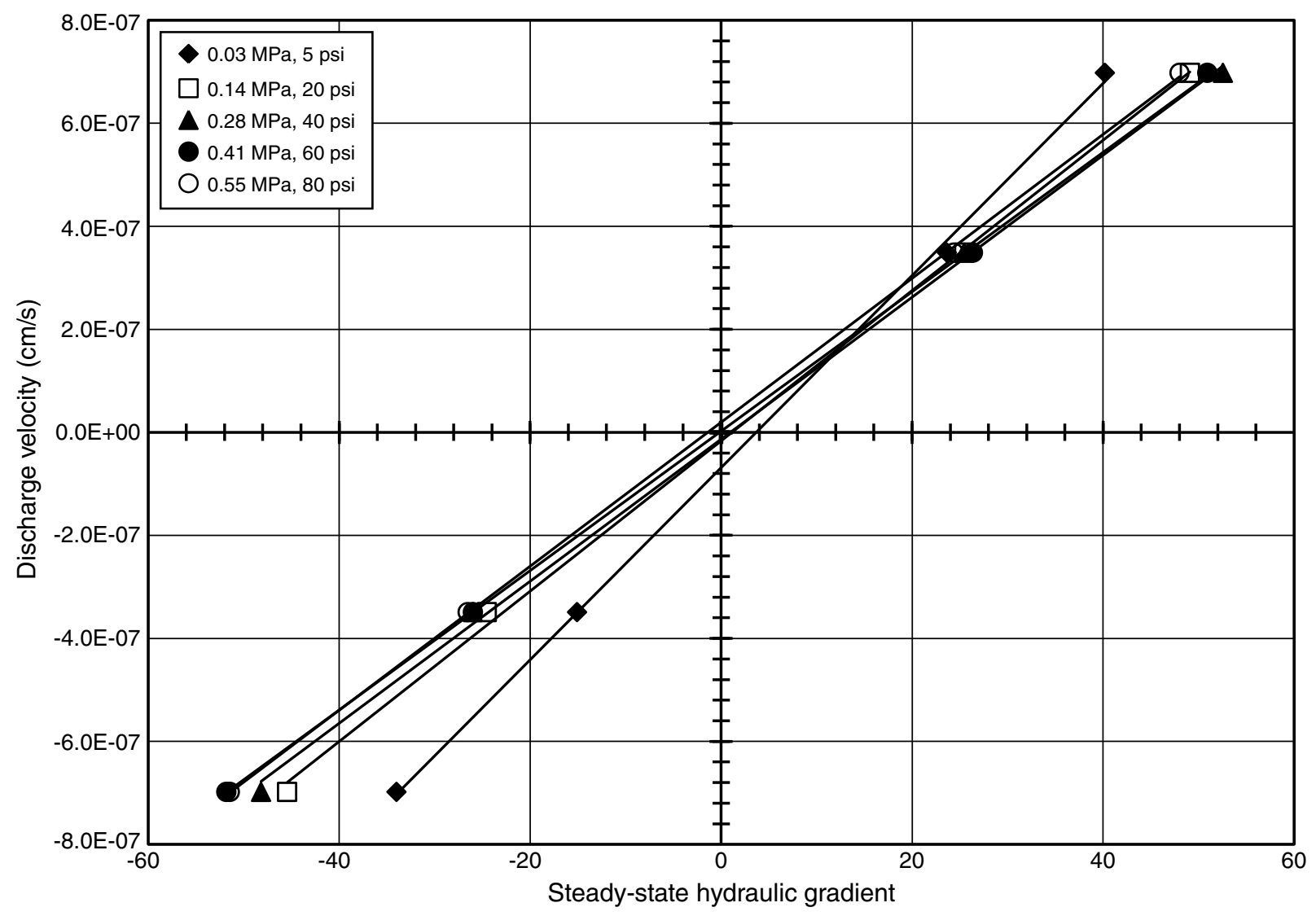


Table AT1. Permeability testing results, Sample 315-C0001E-4H-2, 74-95 cm, vertical.

\begin{tabular}{|c|c|c|c|c|c|c|c|}
\hline $\begin{array}{l}\text { Effective } \\
\text { stress } \\
\mathrm{MPa}(\mathrm{psi})\end{array}$ & $\begin{array}{l}\text { Test } \\
\text { run }\end{array}$ & $\begin{array}{l}\text { Volumetric } \\
\text { flow rate } \\
\left(\mathrm{cm}^{3} / \mathrm{min}\right)\end{array}$ & $\begin{array}{l}\text { Discharge } \\
\text { velocity } \\
(\mathrm{cm} / \mathrm{s})\end{array}$ & $\begin{array}{l}\text { Head loss } \\
(\mathrm{cm})\end{array}$ & $\begin{array}{c}\text { Hydraulic } \\
\text { gradient }\end{array}$ & $\begin{array}{l}\text { Hydraulic } \\
\text { conductivity } \\
(\mathrm{cm} / \mathrm{s})\end{array}$ & $\begin{array}{c}\text { Intrinsic } \\
\text { permeability } \\
\left(\mathrm{m}^{2}\right)\end{array}$ \\
\hline \multirow[t]{5}{*}{$0.03(5)$} & 1 & 0.006 & $8.24 \mathrm{E}-06$ & 174 & 32.8 & $2.51 \mathrm{E}-07$ & $2.49 \mathrm{E}-16$ \\
\hline & 2 & -0.006 & $-8.24 \mathrm{E}-06$ & -167 & -31.5 & $2.62 \mathrm{E}-07$ & $2.60 \mathrm{E}-16$ \\
\hline & 3 & 0.010 & 1.37E-05 & 285 & 53.8 & $2.56 \mathrm{E}-07$ & $2.54 \mathrm{E}-16$ \\
\hline & 4 & -0.010 & $-1.37 \mathrm{E}-05$ & -280 & -52.8 & $2.60 \mathrm{E}-07$ & $2.58 \mathrm{E}-16$ \\
\hline & & & & & Average: & $2.57 \mathrm{E}-07$ & $2.55 \mathrm{E}-16$ \\
\hline \multirow[t]{5}{*}{$0.14(20)$} & 1 & 0.003 & $4.12 \mathrm{E}-06$ & 118 & 22.3 & $1.85 \mathrm{E}-07$ & $1.84 \mathrm{E}-16$ \\
\hline & 2 & -0.003 & $-4.12 \mathrm{E}-06$ & -116 & -21.9 & $1.88 \mathrm{E}-07$ & $1.87 \mathrm{E}-16$ \\
\hline & 3 & -0.006 & $-8.24 \mathrm{E}-06$ & -242 & -45.7 & $1.81 \mathrm{E}-07$ & $1.79 \mathrm{E}-16$ \\
\hline & 4 & 0.006 & $8.24 \mathrm{E}-06$ & 258 & 48.7 & $1.69 \mathrm{E}-07$ & $1.68 \mathrm{E}-16$ \\
\hline & & & & & Average: & $1.81 \mathrm{E}-07$ & $1.79 \mathrm{E}-16$ \\
\hline \multirow[t]{5}{*}{$0.28(40)$} & 1 & 0.003 & $4.12 \mathrm{E}-06$ & 179 & 33.8 & $1.22 \mathrm{E}-07$ & $1.21 \mathrm{E}-16$ \\
\hline & 2 & 0.002 & $2.75 \mathrm{E}-06$ & 120 & 22.6 & $1.21 \mathrm{E}-07$ & $1.20 \mathrm{E}-16$ \\
\hline & 3 & -0.002 & $-2.75 \mathrm{E}-06$ & -124 & -23.4 & 1.17E-07 & $1.17 \mathrm{E}-16$ \\
\hline & 4 & -0.003 & $-4.12 \mathrm{E}-06$ & -192 & -36.2 & $1.14 \mathrm{E}-07$ & $1.13 \mathrm{E}-16$ \\
\hline & & & & & Average: & $1.19 \mathrm{E}-07$ & $1.18 \mathrm{E}-16$ \\
\hline \multirow[t]{5}{*}{$0.41(60)$} & 1 & 0.003 & $4.12 \mathrm{E}-06$ & 227 & 42.8 & $9.62 \mathrm{E}-08$ & $9.55 \mathrm{E}-17$ \\
\hline & 2 & 0.002 & $2.75 \mathrm{E}-06$ & 149 & 28.1 & $9.77 \mathrm{E}-08$ & $9.70 \mathrm{E}-17$ \\
\hline & 3 & -0.002 & $-2.75 \mathrm{E}-06$ & -152 & -28.7 & $9.58 \mathrm{E}-08$ & $9.51 \mathrm{E}-17$ \\
\hline & 4 & -0.003 & $-4.12 \mathrm{E}-06$ & -226 & -42.6 & 9.67E-08 & $9.59 \mathrm{E}-17$ \\
\hline & & & & & Average: & $9.66 \mathrm{E}-08$ & $9.59 \mathrm{E}-17$ \\
\hline \multirow[t]{5}{*}{$0.55(80)$} & 1 & 0.002 & $2.75 \mathrm{E}-06$ & 205 & 38.7 & $7.10 \mathrm{E}-08$ & $7.05 \mathrm{E}-17$ \\
\hline & 2 & -0.002 & $-2.75 E-06$ & -202 & -38.1 & $7.21 \mathrm{E}-08$ & $7.16 \mathrm{E}-17$ \\
\hline & 3 & 0.001 & $1.37 \mathrm{E}-06$ & 92 & 17.4 & $7.92 \mathrm{E}-08$ & $7.86 \mathrm{E}-17$ \\
\hline & 4 & -0.001 & $-1.37 \mathrm{E}-06$ & -100 & -18.9 & $7.28 \mathrm{E}-08$ & $7.23 \mathrm{E}-17$ \\
\hline & & & & & Average: & $7.38 \mathrm{E}-08$ & $7.32 \mathrm{E}-17$ \\
\hline
\end{tabular}

Positive values of volumetric flow rate and discharge velocity indicate bottom to top flow through the specimen; negative values indicate top to bottom flow. 
Table AT2. Permeability testing results, Sample 315-C0001E-4H-2, 74-95 cm, horizontal.

\begin{tabular}{|c|c|c|c|c|c|c|c|}
\hline $\begin{array}{l}\text { Effective } \\
\text { stress } \\
\mathrm{MPa}(p s i)\end{array}$ & $\begin{array}{l}\text { Test } \\
\text { run }\end{array}$ & $\begin{array}{l}\text { Volumetric } \\
\text { flow rate } \\
\left(\mathrm{cm}^{3} / \mathrm{min}\right)\end{array}$ & $\begin{array}{l}\text { Discharge } \\
\text { velocity } \\
(\mathrm{cm} / \mathrm{s})\end{array}$ & $\begin{array}{l}\text { Head loss } \\
(\mathrm{cm})\end{array}$ & $\begin{array}{c}\text { Hydraulic } \\
\text { gradient }\end{array}$ & $\begin{array}{l}\text { Hydraulic } \\
\text { conductivity } \\
(\mathrm{cm} / \mathrm{s})\end{array}$ & $\begin{array}{c}\text { Intrinsic } \\
\text { permeability } \\
\left(\mathrm{m}^{2}\right)\end{array}$ \\
\hline \multirow[t]{5}{*}{$0.03(5)$} & 1 & 0.006 & $9.40 \mathrm{E}-06$ & 125 & 24.0 & $3.92 \mathrm{E}-07$ & $3.89 \mathrm{E}-16$ \\
\hline & 2 & 0.004 & $6.27 \mathrm{E}-06$ & 85 & 16.3 & $3.85 \mathrm{E}-07$ & $3.82 \mathrm{E}-16$ \\
\hline & 3 & -0.004 & $-6.27 \mathrm{E}-06$ & -86 & -16.5 & $3.80 \mathrm{E}-07$ & 3.77E-16 \\
\hline & 4 & -0.006 & $-9.40 \mathrm{E}-06$ & -135 & -26.0 & $3.62 \mathrm{E}-07$ & $3.59 \mathrm{E}-16$ \\
\hline & & & & & Average: & $3.79 \mathrm{E}-07$ & $3.77 \mathrm{E}-16$ \\
\hline \multirow[t]{5}{*}{$0.14(20)$} & 1 & 0.003 & 4.70E-06 & 95 & 18.3 & $2.57 \mathrm{E}-07$ & 2.55E-16 \\
\hline & 2 & 0.002 & $3.13 \mathrm{E}-06$ & 62 & 11.9 & $2.63 \mathrm{E}-07$ & $2.61 \mathrm{E}-16$ \\
\hline & 3 & -0.002 & $-3.13 \mathrm{E}-06$ & -70 & -13.5 & $2.32 \mathrm{E}-07$ & 2.30E-16 \\
\hline & 4 & -0.003 & $-4.70 \mathrm{E}-06$ & -108 & -20.8 & $2.26 \mathrm{E}-07$ & $2.24 \mathrm{E}-16$ \\
\hline & & & & & Average: & $2.44 \mathrm{E}-07$ & $2.43 \mathrm{E}-16$ \\
\hline \multirow[t]{5}{*}{$0.28(40)$} & 1 & -0.002 & $-3.13 \mathrm{E}-06$ & -102 & -19.6 & $1.60 \mathrm{E}-07$ & $1.59 \mathrm{E}-16$ \\
\hline & 2 & -0.001 & $-1.57 \mathrm{E}-06$ & -50 & -9.6 & $1.64 \mathrm{E}-07$ & $1.62 \mathrm{E}-16$ \\
\hline & 3 & 0.001 & 1.57E-06 & 50 & 9.6 & $1.64 \mathrm{E}-07$ & 1.62E-16 \\
\hline & 4 & 0.002 & $3.13 \mathrm{E}-06$ & 99 & 19.0 & $1.65 \mathrm{E}-07$ & $1.64 \mathrm{E}-16$ \\
\hline & & & & & Average: & $1.63 \mathrm{E}-07$ & $1.62 \mathrm{E}-16$ \\
\hline \multirow[t]{5}{*}{$0.41(60)$} & 1 & 0.002 & $3.13 \mathrm{E}-06$ & 117 & 22.5 & 1.39E-07 & 1.38E-16 \\
\hline & 2 & 0.001 & 1.57E-06 & 57 & 11.0 & $1.43 \mathrm{E}-07$ & $1.42 \mathrm{E}-16$ \\
\hline & 3 & -0.002 & $-3.13 \mathrm{E}-06$ & -115 & -22.1 & $1.42 \mathrm{E}-07$ & $1.41 \mathrm{E}-16$ \\
\hline & 4 & -0.001 & $-1.57 \mathrm{E}-06$ & -58 & -11.2 & $1.40 \mathrm{E}-07$ & $1.39 \mathrm{E}-16$ \\
\hline & & & & & Average: & $1.41 \mathrm{E}-07$ & $1.40 \mathrm{E}-16$ \\
\hline \multirow[t]{5}{*}{$0.55(80)$} & 1 & -0.002 & $-3.13 \mathrm{E}-06$ & -140 & -26.9 & $1.16 \mathrm{E}-07$ & 1.15E-16 \\
\hline & 2 & -0.001 & $-1.57 \mathrm{E}-06$ & -80 & -15.4 & $1.02 \mathrm{E}-07$ & $1.01 \mathrm{E}-16$ \\
\hline & 3 & 0.001 & 1.57E-06 & 65 & 12.5 & $1.26 \mathrm{E}-07$ & 1.25E-16 \\
\hline & 4 & 0.002 & $3.13 \mathrm{E}-06$ & 150 & 28.8 & $1.09 \mathrm{E}-07$ & $1.08 \mathrm{E}-16$ \\
\hline & & & & & Average: & $1.13 \mathrm{E}-07$ & $1.12 \mathrm{E}-16$ \\
\hline
\end{tabular}

Positive values of volumetric flow rate and discharge velocity indicate bottom to top flow through the specimen; negative values indicate top to bottom flow. 
Table AT3. Permeability testing results, Sample 315-C0001F-3H-2, 80-100 cm, vertical.

\begin{tabular}{|c|c|c|c|c|c|c|c|}
\hline $\begin{array}{l}\text { Effective } \\
\text { stress } \\
\text { MPa (psi) }\end{array}$ & $\begin{array}{l}\text { Test } \\
\text { run }\end{array}$ & $\begin{array}{l}\text { Volumetric } \\
\text { flow rate } \\
\left(\mathrm{cm}^{3} / \mathrm{min}\right)\end{array}$ & $\begin{array}{c}\text { Discharge } \\
\text { velocity } \\
(\mathrm{cm} / \mathrm{s})\end{array}$ & $\begin{array}{l}\text { Head loss } \\
(\mathrm{cm})\end{array}$ & $\begin{array}{c}\text { Hydraulic } \\
\text { gradient }\end{array}$ & $\begin{array}{l}\text { Hydraulic } \\
\text { conductivity } \\
(\mathrm{cm} / \mathrm{s})\end{array}$ & $\begin{array}{c}\text { Intrinsic } \\
\text { permeability } \\
\left(\mathrm{m}^{2}\right)\end{array}$ \\
\hline \multirow[t]{5}{*}{$0.03(5)$} & 1 & -0.006 & $-9.30 \mathrm{E}-06$ & -73 & -12.4 & $7.50 \mathrm{E}-07$ & $7.44 \mathrm{E}-16$ \\
\hline & 2 & -0.004 & $-6.27 \mathrm{E}-06$ & -50 & -8.5 & $7.38 \mathrm{E}-07$ & $7.32 \mathrm{E}-16$ \\
\hline & 3 & 0.004 & $6.27 \mathrm{E}-06$ & 52 & 8.8 & $7.13 \mathrm{E}-07$ & $7.07 \mathrm{E}-16$ \\
\hline & 4 & 0.006 & $9.30 \mathrm{E}-06$ & 76 & 12.9 & $7.21 \mathrm{E}-07$ & $7.16 \mathrm{E}-16$ \\
\hline & & & & & Average: & $7.30 \mathrm{E}-07$ & $7.25 \mathrm{E}-16$ \\
\hline \multirow[t]{5}{*}{$0.14(20)$} & 1 & 0.003 & $4.65 \mathrm{E}-06$ & 106 & 18.0 & $2.58 \mathrm{E}-07$ & $2.56 \mathrm{E}-16$ \\
\hline & 2 & -0.002 & $-3.13 \mathrm{E}-06$ & -67 & -11.4 & $2.75 \mathrm{E}-07$ & $2.73 \mathrm{E}-16$ \\
\hline & 3 & 0.002 & $3.13 \mathrm{E}-06$ & 72 & 12.2 & $2.57 \mathrm{E}-07$ & $2.55 \mathrm{E}-16$ \\
\hline & 4 & -0.003 & $-4.70 \mathrm{E}-06$ & -100 & -16.9 & $2.78 \mathrm{E}-07$ & $2.76 \mathrm{E}-16$ \\
\hline & & & & & Average: & $2.67 \mathrm{E}-07$ & $2.65 \mathrm{E}-16$ \\
\hline \multirow[t]{5}{*}{$0.28(40)$} & 1 & -0.002 & $-3.13 \mathrm{E}-06$ & -108 & -18.3 & $1.71 \mathrm{E}-07$ & $1.70 \mathrm{E}-16$ \\
\hline & 2 & 0.002 & $3.13 \mathrm{E}-06$ & 98 & 16.6 & $1.89 \mathrm{E}-07$ & $1.87 \mathrm{E}-16$ \\
\hline & 3 & -0.001 & $-1.57 \mathrm{E}-06$ & -54 & -9.2 & $1.71 \mathrm{E}-07$ & $1.69 \mathrm{E}-16$ \\
\hline & 4 & 0.001 & $1.57 \mathrm{E}-06$ & 46 & 7.8 & $2.01 \mathrm{E}-07$ & $2.00 \mathrm{E}-16$ \\
\hline & & & & & Average: & $1.83 \mathrm{E}-07$ & $1.82 \mathrm{E}-16$ \\
\hline \multirow[t]{5}{*}{$0.41(60)$} & 1 & 0.002 & $3.13 \mathrm{E}-06$ & 125 & 21.2 & $1.48 \mathrm{E}-07$ & $1.47 \mathrm{E}-16$ \\
\hline & 2 & -0.001 & $-1.57 \mathrm{E}-06$ & -62 & -10.5 & $1.50 \mathrm{E}-07$ & $1.48 \mathrm{E}-16$ \\
\hline & 3 & -0.002 & $-3.13 \mathrm{E}-06$ & -122 & -20.7 & $1.51 \mathrm{E}-07$ & $1.50 \mathrm{E}-16$ \\
\hline & 4 & 0.001 & $1.57 \mathrm{E}-06$ & 60 & 10.2 & $1.54 \mathrm{E}-07$ & $1.53 \mathrm{E}-16$ \\
\hline & & & & & Average: & $1.51 \mathrm{E}-07$ & $1.49 \mathrm{E}-16$ \\
\hline \multirow[t]{5}{*}{$0.55(80)$} & 1 & -0.002 & $-3.13 \mathrm{E}-06$ & -143 & -24.2 & $1.29 \mathrm{E}-07$ & $1.28 \mathrm{E}-16$ \\
\hline & 2 & 0.002 & $3.13 \mathrm{E}-06$ & 142 & 24.1 & $1.30 \mathrm{E}-07$ & $1.29 \mathrm{E}-16$ \\
\hline & 3 & -0.001 & $-1.57 \mathrm{E}-06$ & -73 & -12.4 & $1.27 \mathrm{E}-07$ & $1.26 \mathrm{E}-16$ \\
\hline & 4 & 0.001 & $1.57 \mathrm{E}-06$ & 67 & 11.4 & $1.38 \mathrm{E}-07$ & $1.37 \mathrm{E}-16$ \\
\hline & & & & & Average: & $1.31 \mathrm{E}-07$ & $1.30 \mathrm{E}-16$ \\
\hline
\end{tabular}

Positive values of volumetric flow rate and discharge velocity indicate bottom to top flow through the specimen; negative values indicate top to bottom flow. 
Table AT4. Permeability testing results, Sample 315-C0001F-3H-2, 80-100 cm, horizontal.

\begin{tabular}{|c|c|c|c|c|c|c|c|}
\hline $\begin{array}{l}\text { Effective } \\
\text { stress } \\
\text { MPa (psi) }\end{array}$ & $\begin{array}{l}\text { Test } \\
\text { run }\end{array}$ & $\begin{array}{l}\text { Volumetric } \\
\text { flow rate } \\
\left(\mathrm{cm}^{3} / \mathrm{min}\right)\end{array}$ & $\begin{array}{c}\text { Discharge } \\
\text { velocity } \\
(\mathrm{cm} / \mathrm{s})\end{array}$ & $\begin{array}{l}\text { Head loss } \\
(\mathrm{cm})\end{array}$ & $\begin{array}{c}\text { Hydraulic } \\
\text { gradient }\end{array}$ & $\begin{array}{l}\text { Hydraulic } \\
\text { conductivity } \\
(\mathrm{cm} / \mathrm{s})\end{array}$ & $\begin{array}{c}\text { Intrinsic } \\
\text { permeability } \\
\left(\mathrm{m}^{2}\right)\end{array}$ \\
\hline \multirow[t]{5}{*}{$0.03(5)$} & 1 & -0.006 & $-1.10 \mathrm{E}-05$ & -120 & -21.8 & $5.05 \mathrm{E}-07$ & $5.01 \mathrm{E}-16$ \\
\hline & 2 & -0.004 & $-7.34 \mathrm{E}-06$ & -88 & -16.0 & $4.59 \mathrm{E}-07$ & $4.55 \mathrm{E}-16$ \\
\hline & 3 & 0.004 & 7.34E-06 & 75 & 13.6 & $5.40 \mathrm{E}-07$ & $5.36 \mathrm{E}-16$ \\
\hline & 4 & 0.006 & $1.10 \mathrm{E}-05$ & 121 & 22.0 & $5.00 \mathrm{E}-07$ & $4.96 \mathrm{E}-16$ \\
\hline & & & & & Average: & $5.01 \mathrm{E}-07$ & 4.97E-16 \\
\hline \multirow[t]{5}{*}{$0.14(20)$} & 1 & -0.003 & $-5.51 \mathrm{E}-06$ & -131 & -23.8 & $2.32 \mathrm{E}-07$ & $2.30 \mathrm{E}-16$ \\
\hline & 2 & -0.002 & $-3.67 \mathrm{E}-06$ & -92 & -16.7 & $2.20 \mathrm{E}-07$ & $2.18 \mathrm{E}-16$ \\
\hline & 3 & 0.002 & $3.67 \mathrm{E}-06$ & 75 & 13.6 & $2.70 \mathrm{E}-07$ & $2.68 \mathrm{E}-16$ \\
\hline & 4 & 0.003 & $5.51 \mathrm{E}-06$ & 110 & 20.0 & $2.76 \mathrm{E}-07$ & $2.73 \mathrm{E}-16$ \\
\hline & & & & & Average: & $2.49 \mathrm{E}-07$ & $2.47 \mathrm{E}-16$ \\
\hline \multirow[t]{5}{*}{$0.28(40)$} & 1 & -0.002 & $-3.67 E-06$ & -126 & -22.9 & $1.60 \mathrm{E}-07$ & $1.59 \mathrm{E}-16$ \\
\hline & 2 & -0.001 & $-1.84 \mathrm{E}-06$ & -67 & -12.2 & $1.51 \mathrm{E}-07$ & $1.50 \mathrm{E}-16$ \\
\hline & 3 & 0.001 & $1.84 \mathrm{E}-06$ & 49 & 8.9 & $2.07 \mathrm{E}-07$ & $2.05 \mathrm{E}-16$ \\
\hline & 4 & 0.002 & $3.67 \mathrm{E}-06$ & 101 & 18.4 & $1.99 \mathrm{E}-07$ & $1.98 \mathrm{E}-16$ \\
\hline & & & & & Average: & $1.79 \mathrm{E}-07$ & $1.78 \mathrm{E}-16$ \\
\hline \multirow[t]{5}{*}{$0.41(60)$} & 1 & -0.002 & $-3.67 E-06$ & -142 & -25.8 & $1.42 \mathrm{E}-07$ & $1.41 \mathrm{E}-16$ \\
\hline & 2 & -0.001 & $-1.84 \mathrm{E}-06$ & -77 & -14.0 & $1.31 \mathrm{E}-07$ & $1.30 \mathrm{E}-16$ \\
\hline & 3 & 0.001 & $1.84 \mathrm{E}-06$ & 61 & 11.1 & $1.66 \mathrm{E}-07$ & $1.65 \mathrm{E}-16$ \\
\hline & 4 & 0.002 & $3.67 \mathrm{E}-06$ & 144 & 26.2 & $1.40 \mathrm{E}-07$ & $1.39 \mathrm{E}-16$ \\
\hline & & & & & Average: & $1.45 \mathrm{E}-07$ & $1.44 \mathrm{E}-16$ \\
\hline \multirow[t]{5}{*}{$0.55(80)$} & 1 & -0.002 & $-3.67 \mathrm{E}-06$ & -170 & -30.9 & $1.19 \mathrm{E}-07$ & $1.18 \mathrm{E}-16$ \\
\hline & 2 & -0.001 & $-1.84 \mathrm{E}-06$ & -77 & -14.0 & $1.31 \mathrm{E}-07$ & $1.30 \mathrm{E}-16$ \\
\hline & 3 & 0.001 & $1.84 \mathrm{E}-06$ & 75 & 13.6 & $1.35 \mathrm{E}-07$ & $1.34 \mathrm{E}-16$ \\
\hline & 4 & 0.002 & $3.67 \mathrm{E}-06$ & 155 & 28.2 & $1.30 \mathrm{E}-07$ & $1.29 \mathrm{E}-16$ \\
\hline & & & & & Average: & $1.29 \mathrm{E}-07$ & $1.28 \mathrm{E}-16$ \\
\hline
\end{tabular}

Positive values of volumetric flow rate and discharge velocity indicate bottom to top flow through the specimen; negative values indicate top to bottom flow. 
Table AT5. Permeability testing results, Sample 315-C0001F-10H-11, 15-35 cm, vertical.

\begin{tabular}{|c|c|c|c|c|c|c|c|}
\hline $\begin{array}{l}\text { Effective } \\
\text { stress } \\
\mathrm{MPa}(p s i)\end{array}$ & $\begin{array}{l}\text { Test } \\
\text { run }\end{array}$ & $\begin{array}{l}\text { Volumetric } \\
\text { flow rate } \\
\left(\mathrm{cm}^{3} / \mathrm{min}\right)\end{array}$ & $\begin{array}{l}\text { Discharge } \\
\text { velocity } \\
(\mathrm{cm} / \mathrm{s})\end{array}$ & $\begin{array}{l}\text { Head loss } \\
\quad(\mathrm{cm})\end{array}$ & $\begin{array}{c}\text { Hydraulic } \\
\text { gradient }\end{array}$ & $\begin{array}{c}\text { Hydraulic } \\
\text { conductivity } \\
(\mathrm{cm} / \mathrm{s})\end{array}$ & $\begin{array}{c}\text { Intrinsic } \\
\text { permeability } \\
\left(\mathrm{m}^{2}\right)\end{array}$ \\
\hline \multirow[t]{5}{*}{$0.03(5)$} & 1 & 0.002 & $2.52 \mathrm{E}-06$ & 300 & 51.7 & 4.87E-08 & $4.84 \mathrm{E}-17$ \\
\hline & 2 & 0.001 & $1.26 \mathrm{E}-06$ & 160 & 27.6 & $4.57 \mathrm{E}-08$ & $4.53 \mathrm{E}-17$ \\
\hline & 3 & -0.001 & $-1.26 \mathrm{E}-06$ & -150 & -25.9 & $4.86 \mathrm{E}-08$ & $4.83 \mathrm{E}-17$ \\
\hline & 4 & -0.002 & $-2.52 \mathrm{E}-06$ & -280 & -48.3 & $5.22 \mathrm{E}-08$ & $5.18 \mathrm{E}-17$ \\
\hline & & & & & Average: & $4.88 \mathrm{E}-08$ & $4.84 \mathrm{E}-17$ \\
\hline \multirow[t]{5}{*}{$0.14(20)$} & 1 & 0.002 & $2.52 \mathrm{E}-06$ & 350 & 60.3 & $4.18 \mathrm{E}-08$ & $4.15 \mathrm{E}-17$ \\
\hline & 2 & 0.001 & $1.26 \mathrm{E}-06$ & 175 & 30.2 & 4.17E-08 & $4.14 \mathrm{E}-17$ \\
\hline & 3 & -0.001 & $-1.26 \mathrm{E}-06$ & -230 & -39.7 & $3.17 \mathrm{E}-08$ & $3.15 \mathrm{E}-17$ \\
\hline & 4 & -0.002 & $-2.52 \mathrm{E}-06$ & -305 & -52.6 & $4.79 \mathrm{E}-08$ & $4.76 \mathrm{E}-17$ \\
\hline & & & & & Average: & $4.08 \mathrm{E}-08$ & $4.05 \mathrm{E}-17$ \\
\hline \multirow[t]{5}{*}{$0.28(40)$} & 1 & 0.002 & $2.52 \mathrm{E}-06$ & 395 & 68.1 & $3.70 \mathrm{E}-08$ & $3.67 \mathrm{E}-17$ \\
\hline & 2 & -0.001 & $-1.26 \mathrm{E}-06$ & -125 & -21.6 & $5.83 \mathrm{E}-08$ & $5.79 \mathrm{E}-17$ \\
\hline & 3 & 0.001 & $1.26 \mathrm{E}-06$ & 205 & 35.3 & $3.57 \mathrm{E}-08$ & $3.54 \mathrm{E}-17$ \\
\hline & 4 & -0.002 & $-2.52 \mathrm{E}-06$ & -310 & -53.4 & $4.72 \mathrm{E}-08$ & $4.68 \mathrm{E}-17$ \\
\hline & & & & & Average: & $4.46 \mathrm{E}-08$ & $4.42 \mathrm{E}-17$ \\
\hline \multirow[t]{5}{*}{$0.41(60)$} & 1 & 0.002 & $2.52 \mathrm{E}-06$ & 375 & 64.7 & $3.89 \mathrm{E}-08$ & $3.87 \mathrm{E}-17$ \\
\hline & 2 & 0.001 & $1.26 \mathrm{E}-06$ & 195 & 33.6 & $3.75 \mathrm{E}-08$ & $3.72 \mathrm{E}-17$ \\
\hline & 3 & -0.001 & $-1.26 \mathrm{E}-06$ & -180 & -31.0 & $4.06 \mathrm{E}-08$ & $4.03 \mathrm{E}-17$ \\
\hline & 4 & -0.002 & $-2.52 \mathrm{E}-06$ & -335 & -57.8 & $4.36 \mathrm{E}-08$ & $4.33 \mathrm{E}-17$ \\
\hline & & & & & Average: & $4.02 \mathrm{E}-08$ & $3.99 \mathrm{E}-17$ \\
\hline \multirow[t]{5}{*}{$0.55(80)$} & 1 & 0.002 & $2.52 \mathrm{E}-06$ & 385 & 66.4 & $3.80 \mathrm{E}-08$ & 3.77E-17 \\
\hline & 2 & 0.001 & $1.26 \mathrm{E}-06$ & 200 & 34.5 & $3.65 \mathrm{E}-08$ & $3.63 \mathrm{E}-17$ \\
\hline & 3 & -0.001 & $-1.26 \mathrm{E}-06$ & -180 & -31.0 & $4.06 \mathrm{E}-08$ & $4.03 \mathrm{E}-17$ \\
\hline & 4 & -0.002 & $-2.52 \mathrm{E}-06$ & -380 & -65.5 & $3.85 \mathrm{E}-08$ & $3.82 \mathrm{E}-17$ \\
\hline & & & & & Average: & $3.84 \mathrm{E}-08$ & $3.81 \mathrm{E}-17$ \\
\hline
\end{tabular}

Positive values of volumetric flow rate and discharge velocity indicate bottom to top flow through the specimen; negative values indicate top to bottom flow. 
Table AT6. Permeability testing results, Sample 315-C0001F-10H-11, 15-35 cm, horizontal.

\begin{tabular}{|c|c|c|c|c|c|c|c|}
\hline $\begin{array}{l}\text { Effective } \\
\text { stress } \\
\mathrm{MPa}(p s i)\end{array}$ & $\begin{array}{l}\text { Test } \\
\text { run }\end{array}$ & $\begin{array}{l}\text { Volumetric } \\
\text { flow rate } \\
\left(\mathrm{cm}^{3} / \mathrm{min}\right)\end{array}$ & $\begin{array}{l}\text { Discharge } \\
\text { velocity } \\
(\mathrm{cm} / \mathrm{s})\end{array}$ & $\begin{array}{l}\text { Head loss } \\
\quad(\mathrm{cm})\end{array}$ & $\begin{array}{c}\text { Hydraulic } \\
\text { gradient }\end{array}$ & $\begin{array}{c}\text { Hydraulic } \\
\text { conductivity } \\
(\mathrm{cm} / \mathrm{s})\end{array}$ & $\begin{array}{c}\text { Intrinsic } \\
\text { permeability } \\
\left(\mathrm{m}^{2}\right)\end{array}$ \\
\hline \multirow[t]{5}{*}{$0.03(5)$} & 1 & 0.002 & $2.65 \mathrm{E}-06$ & 205 & 34.7 & 7.637E-08 & 7.57E-17 \\
\hline & 2 & 0.001 & $1.33 \mathrm{E}-06$ & 100 & 16.9 & $7.85 \mathrm{E}-08$ & $7.79 \mathrm{E}-17$ \\
\hline & 3 & -0.001 & $-1.33 \mathrm{E}-06$ & -100 & -16.9 & $7.85 \mathrm{E}-08$ & $7.79 \mathrm{E}-17$ \\
\hline & 4 & -0.002 & $-2.65 E-06$ & -220 & -37.3 & $7.11 \mathrm{E}-08$ & $7.05 \mathrm{E}-17$ \\
\hline & & & & & Average: & $7.61 \mathrm{E}-08$ & $7.55 \mathrm{E}-17$ \\
\hline \multirow[t]{5}{*}{$0.14(20)$} & 1 & 0.002 & $2.65 \mathrm{E}-06$ & 283 & 48.0 & $5.52 \mathrm{E}-08$ & $5.48 \mathrm{E}-17$ \\
\hline & 2 & -0.001 & $-1.33 \mathrm{E}-06$ & -145 & -24.6 & $5.41 \mathrm{E}-08$ & $5.37 \mathrm{E}-17$ \\
\hline & 3 & 0.001 & $1.33 \mathrm{E}-06$ & 150 & 25.4 & $5.23 \mathrm{E}-08$ & $5.19 \mathrm{E}-17$ \\
\hline & 4 & -0.002 & $-2.65 \mathrm{E}-06$ & -260 & -44.1 & $6.01 \mathrm{E}-08$ & $5.97 \mathrm{E}-17$ \\
\hline & & & & & Average: & $5.55 \mathrm{E}-08$ & $5.50 \mathrm{E}-17$ \\
\hline \multirow[t]{5}{*}{$0.28(40)$} & 1 & 0.002 & $2.65 \mathrm{E}-06$ & 305 & 51.7 & $5.13 \mathrm{E}-08$ & $5.09 \mathrm{E}-17$ \\
\hline & 2 & -0.001 & $-1.33 \mathrm{E}-06$ & -143 & -24.2 & $5.49 \mathrm{E}-08$ & $5.45 \mathrm{E}-17$ \\
\hline & 3 & 0.001 & $1.33 \mathrm{E}-06$ & 150 & 25.4 & $5.23 \mathrm{E}-08$ & 5.19E-17 \\
\hline & 4 & -0.002 & $-2.65 \mathrm{E}-06$ & -295 & -50.0 & $5.30 \mathrm{E}-08$ & $5.26 \mathrm{E}-17$ \\
\hline & & & & & Average: & $5.29 \mathrm{E}-08$ & $5.25 \mathrm{E}-17$ \\
\hline \multirow[t]{5}{*}{$0.41(60)$} & 1 & 0.002 & $2.65 \mathrm{E}-06$ & 325 & 55.1 & $4.81 \mathrm{E}-08$ & $4.78 \mathrm{E}-17$ \\
\hline & 2 & 0.001 & $1.33 \mathrm{E}-06$ & 160 & 27.1 & $4.90 \mathrm{E}-08$ & $4.87 \mathrm{E}-17$ \\
\hline & 3 & -0.001 & $-1.33 \mathrm{E}-06$ & -191 & -32.4 & $4.11 \mathrm{E}-08$ & $4.08 \mathrm{E}-17$ \\
\hline & 4 & -0.002 & $-2.65 \mathrm{E}-06$ & -345 & -58.5 & $4.53 \mathrm{E}-08$ & $4.50 \mathrm{E}-17$ \\
\hline & & & & & Average: & $4.59 \mathrm{E}-08$ & $4.55 \mathrm{E}-17$ \\
\hline \multirow[t]{5}{*}{$0.55(80)$} & 1 & 0.002 & $2.65 \mathrm{E}-06$ & 328 & 55.6 & $4.77 \mathrm{E}-08$ & $4.73 \mathrm{E}-17$ \\
\hline & 2 & 0.001 & $1.33 \mathrm{E}-06$ & 197 & 33.4 & $3.98 \mathrm{E}-08$ & $3.95 \mathrm{E}-17$ \\
\hline & 3 & -0.001 & $-1.33 \mathrm{E}-06$ & -178 & -30.2 & $4.41 \mathrm{E}-08$ & $4.38 \mathrm{E}-17$ \\
\hline & 4 & -0.002 & $-2.65 \mathrm{E}-06$ & -380 & -64.4 & $4.11 \mathrm{E}-08$ & $4.08 \mathrm{E}-17$ \\
\hline & & & & & Average: & $4.32 \mathrm{E}-08$ & $4.29 \mathrm{E}-17$ \\
\hline
\end{tabular}

Positive values of volumetric flow rate and discharge velocity indicate bottom to top flow through the specimen; negative values indicate top to bottom flow. 
Table AT7. Permeability testing results, Sample 315-C0001F-15H-2, 25-45 cm, vertical.

\begin{tabular}{|c|c|c|c|c|c|c|c|}
\hline $\begin{array}{l}\text { Effective } \\
\text { stress } \\
\mathrm{MPa}(\mathrm{psi})\end{array}$ & $\begin{array}{l}\text { Test } \\
\text { run }\end{array}$ & $\begin{array}{l}\text { Volumetric } \\
\text { flow rate } \\
\left(\mathrm{cm}^{3} / \mathrm{min}\right)\end{array}$ & $\begin{array}{l}\text { Discharge } \\
\text { velocity } \\
(\mathrm{cm} / \mathrm{s})\end{array}$ & $\begin{array}{l}\text { Head loss } \\
(\mathrm{cm})\end{array}$ & $\begin{array}{c}\text { Hydraulic } \\
\text { gradient }\end{array}$ & $\begin{array}{l}\text { Hydraulic } \\
\text { conductivity } \\
(\mathrm{cm} / \mathrm{s})\end{array}$ & $\begin{array}{c}\text { Intrinsic } \\
\text { permeability } \\
\left(\mathrm{m}^{2}\right)\end{array}$ \\
\hline \multirow[t]{5}{*}{$0.03(5)$} & 1 & 0.005 & $7.75 \mathrm{E}-06$ & 200 & 41.7 & $1.86 \mathrm{E}-07$ & $1.85 \mathrm{E}-16$ \\
\hline & 2 & 0.002 & $3.10 \mathrm{E}-06$ & 92 & 19.2 & $1.62 \mathrm{E}-07$ & $1.61 \mathrm{E}-16$ \\
\hline & 3 & -0.002 & $-3.10 \mathrm{E}-06$ & -92 & -19.2 & $1.62 \mathrm{E}-07$ & $1.61 \mathrm{E}-16$ \\
\hline & 4 & -0.005 & $-7.75 E-06$ & -205 & -42.7 & $1.81 \mathrm{E}-07$ & $1.80 \mathrm{E}-16$ \\
\hline & & & & & Average: & $1.73 \mathrm{E}-07$ & $1.71 \mathrm{E}-16$ \\
\hline \multirow[t]{5}{*}{$0.14(20)$} & 1 & 0.005 & 7.75E-06 & 400 & 83.3 & $9.30 \mathrm{E}-08$ & $9.23 \mathrm{E}-17$ \\
\hline & 2 & 0.002 & $3.10 \mathrm{E}-06$ & 170 & 35.4 & $8.75 \mathrm{E}-08$ & $8.69 \mathrm{E}-17$ \\
\hline & 3 & -0.002 & $-3.10 \mathrm{E}-06$ & -180 & -37.5 & $8.27 \mathrm{E}-08$ & $8.21 \mathrm{E}-17$ \\
\hline & 4 & -0.005 & $-7.75 E-06$ & -395 & -82.3 & $9.42 \mathrm{E}-08$ & $9.35 \mathrm{E}-17$ \\
\hline & & & & & Average: & $8.93 \mathrm{E}-08$ & 8.87E-17 \\
\hline \multirow[t]{5}{*}{$0.28(40)$} & 1 & 0.005 & $7.75 \mathrm{E}-06$ & 590 & 122.9 & $6.31 \mathrm{E}-08$ & $6.26 \mathrm{E}-17$ \\
\hline & 2 & 0.002 & $3.10 \mathrm{E}-06$ & 245 & 51.0 & 6.07E-08 & $6.03 \mathrm{E}-17$ \\
\hline & 3 & -0.002 & $-3.10 \mathrm{E}-06$ & -240 & -50.0 & $6.20 \mathrm{E}-08$ & $6.15 \mathrm{E}-17$ \\
\hline & 4 & -0.005 & $-7.75 \mathrm{E}-06$ & -600 & -125.0 & $6.20 \mathrm{E}-08$ & $6.15 \mathrm{E}-17$ \\
\hline & & & & & Average: & $6.19 \mathrm{E}-08$ & $6.15 \mathrm{E}-17$ \\
\hline \multirow[t]{5}{*}{$0.41(60)$} & 1 & 0.005 & $7.75 \mathrm{E}-06$ & 720 & 150.0 & $5.17 \mathrm{E}-08$ & $5.13 \mathrm{E}-17$ \\
\hline & 2 & 0.002 & $3.10 \mathrm{E}-06$ & 290 & 60.4 & $5.13 \mathrm{E}-08$ & $5.09 \mathrm{E}-17$ \\
\hline & 3 & -0.002 & $-3.10 \mathrm{E}-06$ & -300 & -62.5 & 4.96E-08 & $4.92 \mathrm{E}-17$ \\
\hline & 4 & -0.005 & $-7.75 E-06$ & -715 & -149.0 & $5.20 \mathrm{E}-08$ & $5.16 \mathrm{E}-17$ \\
\hline & & & & & Average: & $5.12 \mathrm{E}-08$ & $5.08 \mathrm{E}-17$ \\
\hline \multirow[t]{5}{*}{$0.55(80)$} & 1 & 0.005 & 7.75E-06 & 870 & 181.3 & $4.28 \mathrm{E}-08$ & $4.24 \mathrm{E}-17$ \\
\hline & 2 & 0.002 & $3.10 \mathrm{E}-06$ & 340 & 70.8 & $4.38 \mathrm{E}-08$ & $4.34 \mathrm{E}-17$ \\
\hline & 3 & -0.002 & $-3.10 \mathrm{E}-06$ & -352 & -73.3 & $4.23 \mathrm{E}-08$ & $4.20 \mathrm{E}-17$ \\
\hline & 4 & -0.005 & $-7.75 E-06$ & -866 & -180.4 & 4.30E-08 & $4.26 \mathrm{E}-17$ \\
\hline & & & & & Average: & $4.29 \mathrm{E}-08$ & $4.26 \mathrm{E}-17$ \\
\hline
\end{tabular}

Positive values of volumetric flow rate and discharge velocity indicate bottom to top flow through the specimen; negative values indicate top to bottom flow. 
Table AT8. Permeability testing results, Sample 315-C0001F-15H-2, 25-45 cm, horizontal.

\begin{tabular}{|c|c|c|c|c|c|c|c|}
\hline $\begin{array}{l}\text { Effective } \\
\text { stress } \\
\mathrm{MPa}(\mathrm{psi})\end{array}$ & $\begin{array}{l}\text { Test } \\
\text { run }\end{array}$ & $\begin{array}{l}\text { Volumetric } \\
\text { flow rate } \\
\left(\mathrm{cm}^{3} / \mathrm{min}\right)\end{array}$ & $\begin{array}{l}\text { Discharge } \\
\text { velocity } \\
(\mathrm{cm} / \mathrm{s})\end{array}$ & $\begin{array}{l}\text { Head loss } \\
\quad(\mathrm{cm})\end{array}$ & $\begin{array}{c}\text { Hydraulic } \\
\text { gradient }\end{array}$ & $\begin{array}{c}\text { Hydraulic } \\
\text { conductivity } \\
(\mathrm{cm} / \mathrm{s})\end{array}$ & $\begin{array}{c}\text { Intrinsic } \\
\text { permeability } \\
\left(\mathrm{m}^{2}\right)\end{array}$ \\
\hline \multirow[t]{5}{*}{$0.03(5)$} & 1 & 0.004 & $6.20 \mathrm{E}-06$ & 403 & 85.7 & $7.23 \mathrm{E}-08$ & $7.18 \mathrm{E}-17$ \\
\hline & 2 & 0.002 & $3.10 \mathrm{E}-06$ & 200 & 42.6 & $7.29 \mathrm{E}-08$ & $7.23 \mathrm{E}-17$ \\
\hline & 3 & -0.002 & $-3.10 \mathrm{E}-06$ & -185 & -39.4 & $7.88 \mathrm{E}-08$ & $7.82 \mathrm{E}-17$ \\
\hline & 4 & -0.004 & $-6.20 \mathrm{E}-06$ & -355 & -75.5 & $8.21 \mathrm{E}-08$ & $8.15 \mathrm{E}-17$ \\
\hline & & & & & Average: & $7.65 \mathrm{E}-08$ & $7.59 \mathrm{E}-17$ \\
\hline \multirow[t]{5}{*}{$0.14(20)$} & 1 & 0.004 & $6.20 \mathrm{E}-06$ & 480 & 102.1 & $6.07 \mathrm{E}-08$ & $6.03 \mathrm{E}-17$ \\
\hline & 2 & 0.002 & $3.10 \mathrm{E}-06$ & 210 & 44.7 & $6.94 \mathrm{E}-08$ & $6.89 \mathrm{E}-17$ \\
\hline & 3 & -0.002 & $-3.10 \mathrm{E}-06$ & -260 & -55.3 & $5.60 \mathrm{E}-08$ & $5.56 \mathrm{E}-17$ \\
\hline & 4 & -0.004 & $-6.20 E-06$ & -455 & -96.8 & $6.40 \mathrm{E}-08$ & $6.36 \mathrm{E}-17$ \\
\hline & & & & & Average: & $6.25 \mathrm{E}-08$ & $6.21 \mathrm{E}-17$ \\
\hline \multirow[t]{5}{*}{$0.28(40)$} & 1 & 0.004 & $6.20 \mathrm{E}-06$ & 480 & 102.1 & $6.07 \mathrm{E}-08$ & $6.03 \mathrm{E}-17$ \\
\hline & 2 & 0.002 & $3.10 \mathrm{E}-06$ & 240 & 51.1 & $6.07 \mathrm{E}-08$ & $6.03 \mathrm{E}-17$ \\
\hline & 3 & -0.002 & $-3.10 \mathrm{E}-06$ & -250 & -53.2 & $5.83 \mathrm{E}-08$ & $5.78 \mathrm{E}-17$ \\
\hline & 4 & -0.004 & $-6.20 \mathrm{E}-06$ & -510 & -108.5 & $5.71 \mathrm{E}-08$ & $5.67 \mathrm{E}-17$ \\
\hline & & & & & Average: & $5.92 \mathrm{E}-08$ & $5.88 \mathrm{E}-17$ \\
\hline \multirow[t]{5}{*}{$0.41(60)$} & 1 & 0.004 & $6.20 \mathrm{E}-06$ & 550 & 117.0 & $5.30 \mathrm{E}-08$ & $5.26 \mathrm{E}-17$ \\
\hline & 2 & 0.002 & $3.10 \mathrm{E}-06$ & 265 & 56.4 & $5.50 \mathrm{E}-08$ & $5.46 \mathrm{E}-17$ \\
\hline & 3 & -0.002 & $-3.10 \mathrm{E}-06$ & -280 & -59.6 & $5.20 \mathrm{E}-08$ & $5.16 \mathrm{E}-17$ \\
\hline & 4 & -0.004 & $-6.20 \mathrm{E}-06$ & -560 & -119.1 & $5.20 \mathrm{E}-08$ & $5.16 \mathrm{E}-17$ \\
\hline & & & & & Average: & $5.30 \mathrm{E}-08$ & $5.26 \mathrm{E}-17$ \\
\hline \multirow[t]{5}{*}{$0.55(80)$} & 1 & 0.004 & $6.20 \mathrm{E}-06$ & 600 & 127.7 & $4.86 \mathrm{E}-08$ & $4.82 \mathrm{E}-17$ \\
\hline & 2 & 0.002 & $3.10 \mathrm{E}-06$ & 291 & 61.9 & $5.01 \mathrm{E}-08$ & 4.97E-17 \\
\hline & 3 & -0.002 & $-3.10 \mathrm{E}-06$ & -300 & -63.8 & $4.86 \mathrm{E}-08$ & $4.82 \mathrm{E}-17$ \\
\hline & 4 & -0.004 & $-6.20 \mathrm{E}-06$ & -610 & -129.8 & $4.78 \mathrm{E}-08$ & $4.74 \mathrm{E}-17$ \\
\hline & & & & & Average: & $4.87 \mathrm{E}-08$ & $4.84 \mathrm{E}-17$ \\
\hline
\end{tabular}

Positive values of volumetric flow rate and discharge velocity indicate bottom to top flow through the specimen; negative values indicate top to bottom flow. 
Table AT9. Permeability testing results, Sample 315-C0001H-7R-3, 21-38 cm, vertical.

\begin{tabular}{|c|c|c|c|c|c|c|c|}
\hline $\begin{array}{l}\text { Effective } \\
\text { stress } \\
\text { MPa (psi) }\end{array}$ & $\begin{array}{l}\text { Test } \\
\text { run }\end{array}$ & $\begin{array}{l}\text { Volumetric } \\
\text { flow rate } \\
\left(\mathrm{cm}^{3} / \mathrm{min}\right)\end{array}$ & $\begin{array}{l}\text { Discharge } \\
\text { velocity } \\
(\mathrm{cm} / \mathrm{s})\end{array}$ & $\begin{array}{l}\text { Head loss } \\
(\mathrm{cm})\end{array}$ & $\begin{array}{c}\text { Hydraulic } \\
\text { gradient }\end{array}$ & $\begin{array}{l}\text { Hydraulic } \\
\text { conductivity } \\
(\mathrm{cm} / \mathrm{s})\end{array}$ & $\begin{array}{c}\text { Intrinsic } \\
\text { permeability } \\
\left(\mathrm{m}^{2}\right)\end{array}$ \\
\hline \multirow[t]{5}{*}{$0.03(5)$} & 1 & -0.00050 & $-6.98 \mathrm{E}-07$ & -180 & -40.9 & $1.71 \mathrm{E}-08$ & $1.69 \mathrm{E}-17$ \\
\hline & 2 & -0.00025 & $-3.49 \mathrm{E}-07$ & -120 & -27.3 & $1.28 \mathrm{E}-08$ & $1.27 \mathrm{E}-17$ \\
\hline & 3 & 0.00025 & $3.49 \mathrm{E}-07$ & 99 & 22.5 & $1.55 \mathrm{E}-08$ & $1.54 \mathrm{E}-17$ \\
\hline & 4 & 0.00050 & $6.98 \mathrm{E}-07$ & 211 & 48.0 & $1.46 \mathrm{E}-08$ & $1.44 \mathrm{E}-17$ \\
\hline & & & & & Average: & $1.50 \mathrm{E}-08$ & $1.49 \mathrm{E}-17$ \\
\hline \multirow[t]{5}{*}{$0.14(20)$} & 1 & -0.00050 & $-6.98 \mathrm{E}-07$ & -250 & -56.8 & $1.23 \mathrm{E}-08$ & $1.22 \mathrm{E}-17$ \\
\hline & 2 & -0.00025 & $-3.49 \mathrm{E}-07$ & -135 & -30.7 & $1.14 \mathrm{E}-08$ & $1.13 \mathrm{E}-17$ \\
\hline & 3 & 0.00025 & $3.49 \mathrm{E}-07$ & 140 & 31.8 & 1.10E-08 & $1.09 \mathrm{E}-17$ \\
\hline & 4 & 0.00050 & $6.98 \mathrm{E}-07$ & 270 & 61.4 & $1.14 \mathrm{E}-08$ & $1.13 \mathrm{E}-17$ \\
\hline & & & & & Average: & $1.15 \mathrm{E}-08$ & $1.14 \mathrm{E}-17$ \\
\hline \multirow[t]{5}{*}{$0.28(40)$} & 1 & -0.00050 & $-6.98 \mathrm{E}-07$ & -250 & -56.8 & $1.23 \mathrm{E}-08$ & $1.22 \mathrm{E}-17$ \\
\hline & 2 & -0.00025 & $-3.49 \mathrm{E}-07$ & -140 & -31.8 & $1.10 \mathrm{E}-08$ & $1.09 \mathrm{E}-17$ \\
\hline & 3 & 0.00025 & $3.49 \mathrm{E}-07$ & 155 & 35.2 & $9.91 \mathrm{E}-09$ & $9.83 \mathrm{E}-18$ \\
\hline & 4 & 0.00050 & $6.98 \mathrm{E}-07$ & 300 & 68.2 & $1.02 \mathrm{E}-08$ & $1.02 \mathrm{E}-17$ \\
\hline & & & & & Average: & $1.08 \mathrm{E}-08$ & $1.08 \mathrm{E}-17$ \\
\hline \multirow[t]{5}{*}{$0.41(60)$} & 1 & -0.00050 & $-6.98 \mathrm{E}-07$ & -270 & -61.4 & $1.14 \mathrm{E}-08$ & $1.13 \mathrm{E}-17$ \\
\hline & 2 & -0.00025 & $-3.49 \mathrm{E}-07$ & -145 & -33.0 & $1.06 \mathrm{E}-08$ & $1.05 \mathrm{E}-17$ \\
\hline & 3 & 0.00025 & $3.49 \mathrm{E}-07$ & 155 & 35.2 & $9.91 \mathrm{E}-09$ & $9.83 \mathrm{E}-18$ \\
\hline & 4 & 0.00050 & $6.98 \mathrm{E}-07$ & 285 & 64.8 & $1.08 \mathrm{E}-08$ & $1.07 \mathrm{E}-17$ \\
\hline & & & & & Average: & $1.07 \mathrm{E}-08$ & $1.06 \mathrm{E}-17$ \\
\hline \multirow[t]{5}{*}{$0.55(80)$} & 1 & -0.00050 & $-6.98 \mathrm{E}-07$ & -282 & -64.1 & $1.09 \mathrm{E}-08$ & $1.08 \mathrm{E}-17$ \\
\hline & 2 & -0.00025 & $-3.49 \mathrm{E}-07$ & -152 & -34.5 & $1.01 \mathrm{E}-08$ & $1.00 \mathrm{E}-17$ \\
\hline & 3 & 0.00025 & $3.49 \mathrm{E}-07$ & 146 & 33.2 & $1.05 \mathrm{E}-08$ & $1.04 \mathrm{E}-17$ \\
\hline & 4 & 0.00050 & $6.98 \mathrm{E}-07$ & 285 & 64.8 & $1.08 \mathrm{E}-08$ & $1.07 \mathrm{E}-17$ \\
\hline & & & & & Average: & $1.06 \mathrm{E}-08$ & $1.05 \mathrm{E}-17$ \\
\hline
\end{tabular}

Positive values of volumetric flow rate and discharge velocity indicate bottom to top flow through the specimen; negative values indicate top to bottom flow. 
Table AT10. Permeability testing results, Sample 315-C0001H-7R-3, 21-38 cm, horizontal.

\begin{tabular}{|c|c|c|c|c|c|c|c|}
\hline $\begin{array}{l}\text { Effective } \\
\text { stress } \\
\text { MPa (psi) }\end{array}$ & $\begin{array}{l}\text { Test } \\
\text { run }\end{array}$ & $\begin{array}{l}\text { Volumetric } \\
\text { flow rate } \\
\left(\mathrm{cm}^{3} / \mathrm{min}\right)\end{array}$ & $\begin{array}{l}\text { Discharge } \\
\text { velocity } \\
(\mathrm{cm} / \mathrm{s})\end{array}$ & $\begin{array}{l}\text { Head loss } \\
\quad(\mathrm{cm})\end{array}$ & $\begin{array}{c}\text { Hydraulic } \\
\text { gradient }\end{array}$ & $\begin{array}{c}\text { Hydraulic } \\
\text { conductivity } \\
(\mathrm{cm} / \mathrm{s})\end{array}$ & $\begin{array}{c}\text { Intrinsic } \\
\text { permeability } \\
\left(\mathrm{m}^{2}\right)\end{array}$ \\
\hline \multirow[t]{5}{*}{$0.03(5)$} & 1 & -0.00050 & $-6.98 E-07$ & -187 & -34.0 & $2.05 \mathrm{E}-08$ & $2.04 \mathrm{E}-17$ \\
\hline & 2 & -0.00025 & $-3.49 \mathrm{E}-07$ & -83 & -15.1 & $2.31 \mathrm{E}-08$ & $2.30 \mathrm{E}-17$ \\
\hline & 3 & 0.00025 & $3.49 \mathrm{E}-07$ & 130 & 23.6 & $1.48 \mathrm{E}-08$ & $1.47 \mathrm{E}-17$ \\
\hline & 4 & 0.00050 & $6.98 \mathrm{E}-07$ & 221 & 40.2 & $1.74 \mathrm{E}-08$ & $1.72 \mathrm{E}-17$ \\
\hline & & & & & Average: & $1.89 \mathrm{E}-08$ & $1.88 \mathrm{E}-17$ \\
\hline \multirow[t]{5}{*}{$0.14(20)$} & 1 & -0.00050 & $-6.98 \mathrm{E}-07$ & -250 & -45.5 & $1.54 \mathrm{E}-08$ & $1.52 \mathrm{E}-17$ \\
\hline & 2 & -0.00025 & $-3.49 \mathrm{E}-07$ & -135 & -24.5 & $1.42 \mathrm{E}-08$ & $1.41 \mathrm{E}-17$ \\
\hline & 3 & 0.00025 & $3.49 \mathrm{E}-07$ & 140 & 25.5 & $1.37 \mathrm{E}-08$ & $1.36 \mathrm{E}-17$ \\
\hline & 4 & 0.00050 & $6.98 \mathrm{E}-07$ & 270 & 49.1 & $1.42 \mathrm{E}-08$ & $1.41 \mathrm{E}-17$ \\
\hline & & & & & Average: & $1.44 \mathrm{E}-08$ & $1.43 \mathrm{E}-17$ \\
\hline \multirow[t]{5}{*}{$0.28(40)$} & 1 & -0.00050 & $-6.98 \mathrm{E}-07$ & -265 & -48.2 & $1.45 \mathrm{E}-08$ & $1.44 \mathrm{E}-17$ \\
\hline & 2 & -0.00025 & $-3.49 \mathrm{E}-07$ & -143 & -26.0 & $1.34 \mathrm{E}-08$ & $1.33 \mathrm{E}-17$ \\
\hline & 3 & 0.00025 & $3.49 \mathrm{E}-07$ & 140 & 25.5 & $1.37 \mathrm{E}-08$ & $1.36 \mathrm{E}-17$ \\
\hline & 4 & 0.00050 & $6.98 \mathrm{E}-07$ & 289 & 52.5 & $1.33 \mathrm{E}-08$ & $1.32 \mathrm{E}-17$ \\
\hline & & & & & Average: & $1.37 \mathrm{E}-08$ & $1.36 \mathrm{E}-17$ \\
\hline \multirow[t]{5}{*}{$0.41(60)$} & 1 & -0.00050 & $-6.98 \mathrm{E}-07$ & -285 & -51.8 & $1.35 \mathrm{E}-08$ & $1.34 \mathrm{E}-17$ \\
\hline & 2 & -0.00025 & $-3.49 \mathrm{E}-07$ & -143 & -26.0 & $1.34 \mathrm{E}-08$ & $1.33 \mathrm{E}-17$ \\
\hline & 3 & 0.00025 & $3.49 \mathrm{E}-07$ & 145 & 26.4 & $1.32 \mathrm{E}-08$ & $1.31 \mathrm{E}-17$ \\
\hline & 4 & 0.00050 & $6.98 \mathrm{E}-07$ & 280 & 50.9 & $1.37 \mathrm{E}-08$ & $1.36 \mathrm{E}-17$ \\
\hline & & & & & Average: & $1.35 \mathrm{E}-08$ & $1.34 \mathrm{E}-17$ \\
\hline \multirow[t]{5}{*}{$0.55(80)$} & 1 & -0.00050 & $-6.98 \mathrm{E}-07$ & -283 & -51.5 & $1.36 \mathrm{E}-08$ & $1.35 \mathrm{E}-17$ \\
\hline & 2 & -0.00025 & $-3.49 \mathrm{E}-07$ & -146 & -26.5 & $1.31 \mathrm{E}-08$ & $1.30 \mathrm{E}-17$ \\
\hline & 3 & 0.00025 & $3.49 \mathrm{E}-07$ & 134 & 24.4 & $1.43 \mathrm{E}-08$ & $1.42 \mathrm{E}-17$ \\
\hline & 4 & 0.00050 & $6.98 \mathrm{E}-07$ & 264 & 48.0 & $1.45 \mathrm{E}-08$ & $1.44 \mathrm{E}-17$ \\
\hline & & & & & Average: & $1.39 \mathrm{E}-08$ & $1.38 \mathrm{E}-17$ \\
\hline
\end{tabular}

Positive values of volumetric flow rate and discharge velocity indicate bottom to top flow through the specimen; negative values indicate top to bottom flow. 